\title{
FINANCING THE CITIES: AN ISSUE AGENDA $†$
}

\section{Colin C. Blaydon* and Steven R. Gilford**}

The financial difficulties encountered by cities during the recent recession and the fiscal crisis which continues to beset New York City have generated widespread interest in the causes of municipal financial distress. For many years, the cities' fiscal capacities to provide basic services were taken wholly for granted. While city residents may have been dissatisfied with the levels of their tax bills, most cities were able to finance virtually all of their services from their own revenues, and there was little opposition to the growth in quantity and quality of urban services. More recently, this situation has changed radically. The expansion of services has combined with escalating costs, increasing resistance to tax increases, and drastic changes in urban population patterns to jeopardize the provision of basic municipal services in some major cities. The specter of cut-backs or actual stoppages in education, garbage collection or police and fire protection has struck citizens at their doorsteps and has focused intense scrutmy on the fiscal strength of cities throughout the country.

Historically, investigations of financial distress have looked primarily at the determinants of municipal expenditures and the availability of resources to meet these expenditures. In recent years, the cities' increas-

$\dagger$ Copyright $@ 1977$ by Colin C. Blaydon and Steven R. Gilford.

* Associate Professor of Policy Sciences and Business Administration, Duke University. B.E.E. 1962, University of Virginia; A.M. 1966, Ph.D. 1967, Harvard University. ** A.B. 1974, Dartmouth College. Public Policy and the Law Program, Duke University.

THE FOLLOWING CITATIONS WILL BE USED IN THIS ARTICLE:

Committee on Community Development, The Domestic Council, 1976 Report on National Growth and Development: The Changing Issues for NaTIONAL GrowTH (1976) [hereinafter cited as 1976 REPORT ON NATIONAL GrowtH AND DEVELOPMENT];

Joint Economic Comm. of Congress, 94th Cong., 1st Sess., New York City's Financial Crisis: an Evaluation of its Economic Impact and of Proposed Policy SOlutions, (Comm. Print 1975) [hereinafter cited as JEC PRINT];

Peterson, Finance, in The URban Predicament 35 (W. Gorham \& N. Glazer ed. 1976) [hereinafter cited as Peterson];

U.S. ADVISORY COMMISSION ON INTERgovernMENTAL RELATIONS, IMPRoving URBAN AMERICA: A Challenge to Federalism (1976) [hereinafter cited as IMProving URBAN AMERICA];

U.S. Advisory Commission on InTERgovernmental Relations, LoCal Revenue Diversification: Income, Sales TAXEs \& User Charges (1974) [hereinafter cited as Local ReVEnue Diversification]. 
ing difficulties in maintaining service levels with their own resources have generated increased interest in two other components of the municipal financial picture-debt financing and state and federal cost-sharing programs. Debt financing is commonly used by many cities to balance short-term seasonal mismatches between revenues and expenditures and to finance long-term capital investments. Because of its central role in the New York City crisis, debt policy has received much more attention in recent discussions of municipal fimance. Substantial interest has also been directed toward the role of state and federal grants-in-aid as the cities have become increasingly dependent on these additional sources of revenue.

The interrelationships of these four components of the cities' fmancial structure-expenditures, revenues generated by the cities themselves, debt financing, and intergovernmental cost sharing-necessarily form the framework for any analysis of governmental finance. In the sections that follow, we will examine the current financial picture for twenty-nine of America's largest cities and outline the major issues of financial policy which face these cities as they adapt to changes in the patterns of urban growth.

\section{Population Trends}

The pattern of shifts in urban population is fundamental to the current fiscal situation of the cities. Because of their limited geographic boundaries and their dependence on property values and business conducted within those boundaries, the cities' financial positions are highly vulnerable to changes in the patterns of urban inigration. Each time a business or family moves outside the city limits, it takes with it a piece of the city's revenue base. The extent to which this loss of revenue is important depends on whether or not there is sufficient immigration to maintain commercial activity and the deınand for land on which land values depend. ${ }^{1}$

City population loss from emigration to the suburbs is not a new phenomenon. Decentralization of population and businesses has been taking place since at least the turn of the century. ${ }^{2}$ While the cities were young this did not create a financial problem, since people and jobs and the revenue base they represented could normally be recaptured through annexation. During the 1950 s, the situation began to change as many older cities began to face difficulties in expanding their bound-

1. See notes 121-26 infra and accompanying text.

2. See Peterson 73. 
aries. ${ }^{3}$ City expansion no longer encroached only on open farm land or newly settled suburban development. The city boundaries were now adjacent to older, established suburban communities (or in some cases younger cities) which liad their own identities and opposed annexation. ${ }^{4}$ In some cases, expansion was impeded by state borders. ${ }^{5}$ More recently, resistance to annexation has been augmented by reaction to desegregation of central city schools.

For whatever reason, by the early 1950 s annexation as an easy solution was no longer available to most of the older cities. ${ }^{6}$ As a result, the cities began to experience a modicum of fiscal strain. While urban population remained fairly stable as immigrants replaced many of those departing for the suburbs, ${ }^{7}$ the cities experienced net revenue losses as their more affluent residents left and were replaced by poorer migrants from the South. ${ }^{8}$ The challenge for these cities was not so much to reduce levels of municipal services, because such services were still needed by the ever-growing metropolitan area at large. Rather, the challenge was to find ways to expand the revenue base to the entire region. To some extent, this has been achieved over the last decade by greater reliance on new revenue sources and federal and state costsliaring. ${ }^{9}$

In the 1970s, lowever, another trend appeared-the population decline of entire metropolitan regions. ${ }^{10}$ This was the result of a process that has been in existence for two decades, the migration of whites from the North and Midwest to the South and West. This decline liad been obscured by the offsetting effects of black migration from the rural South. But when that migration slowed, major metropolitan areas began to lose population. ${ }^{11}$

3. See id. at 76 (Table 13).

4. See note 147 infra and accompanying text.

5. St. Louis and Kansas City, Missouri, are leading examples. Since cities are creatures of the state, a bi-state city is virtually impossible under our federal system of government.

6. Since 1960 , no city over ninety years old has been able to enlarge its geographical territory significantly by annexation. See Peterson 76 (Table 13). See also JEC Print 12 (Table 1). Age is defined as the number of years since the city reached a population of 100,000 . Peterson 77 (Table 13 note a).

7. But cf. Peterson 74 (Figure 2) (population density in aging cities has consistently declined since 1950).

8. See 1976 Report on National Growth and Development 24, 33-34.

9. The proportion of expenditures that is financed by state and local governments from their own sources has fallen from 90 percent to 80 percent over the last two decades. See Sunley, State and Local Government, in Setring National Priorities: The Next Ten Years 382 (Table 9-7) (H. Owen \& C. Shultze ed. 1976).

10. See, e.g., 1976 Report on NATIONAL GRowth and DeVElopment 26-33.

11. See id. at $24-25$. In the 1960 s, net black immigration was 20.2 percent 


\section{TABLE 1}

\section{Changes in Population 1970-1974}

\begin{tabular}{|l|l|l|l} 
Change in & $\begin{array}{l}\text { Change in } \\
\text { Central City }\end{array}$ & $\begin{array}{l}\text { Change in } \\
\text { Sopurbation }\end{array}$ & $\begin{array}{l}\text { Net } \\
\text { Metropolitan }\end{array}$ \\
Population & Metropolitan \\
Population (\%) & Population (\%) & Migration (\%) \\
\hline
\end{tabular}

I. Declining Metropolitan Areas

A. With Declining Suburbs

$\begin{array}{lcccc}\text { New York City } & -4.0 & -1.0 & -3.4 & =5.0 \\ \text { Los Angeles } & =4.0 & 0 & =1.6 & =4.7 \\ \text { Seattle } & =3.4 & -1.0 & =2.0 & =4.4 \\ \text { Pittsburgh } & =9.0 & =1.2 & =2.8 & =3.7 \\ \text { Buffalo } & -3.8 & -.1 & -1.4 & -3.1\end{array}$

B. With Growing Suburbs

$\begin{array}{lcccc}\text { Cleveland } & -13.0 & +1.3 & -3.9 & =6.2 \\ \text { St. Louis } & -12.2 & +2.0 & =1.6 & =4.3 \\ \text { Cincinnati } & =5.4 & +1.6 & -.7 & =3.6 \\ \text { Detroit } & =9.0 & +4.7 & 0 & =3.5 \\ \text { Chicago } & -2.7 & +2.3 & -.1 & =3.2 \\ \text { Philadelphia } & -5.8 & +3.4 & -.3 & =2.3 \\ \text { Milwaukee } & =4.0 & +5.7 & +.8 & =2.0 \\ \text { Kansas City, Mo. } & =2.3 & +5.2 & +2.2 & =1.2 \\ \text { San Francisco } & -8.2 & +3.7 & +.9 & =1.1 \\ \text { Indianapolis } & 0 & +8.8 & +2.9 & =.9 \\ \text { Boston } & 0 & +2.2 & +1.8 & =.1 \\ \text { Memphis* } & +4.7 & -5.6 & +2.3 & -2.0\end{array}$

II. Growing Metropolitan Areas

A. Declining Central Cities

$\begin{array}{lllll}\text { New Orleans } & -2.7 & +13.4 & +4.2 & +.3 \\ \text { Baltimore } & =7.5 & +11.9 & +3.3 & +1.1 \\ \text { Atlanta } & -2.3 & +17.5 & +11.3 & +6.6 \\ \text { Denver } & -3.7 & +24.0 & +12.2 & +8.2\end{array}$

B. Growing Central Cities

$\begin{array}{lllll}\text { Dallas } & +1.2 & +7.2 & +5.1 & +.4 \\ \text { Columbus } & +5.6 & +4.0 & +4.8 & +.8 \\ \text { Honolulu } & +8.0 & +11.5 & +9.6 & +3.0 \\ \text { Jacksonville } & +5.8 & +26.3 & +8.5 & +4.4 \\ \text { San Antonio } & +11.3 & +6.1 & +10.3 & +4.4 \\ \text { Houston } & +4.5 & +22.5 & +11.2 & +5.6 \\ \text { San Diego } & +14.5 & +8.9 & +11.8 & +8.1 \\ \text { Phoenix } & +23.0 & +17.7 & +20.9 & +16.1\end{array}$

- The unique character of Memphis is the result of several large annexations during the period examined which brought an additional 136,562 residents into the Memphis city limits. See JEC PRINT 12 n.7. See also U.S. BUREAU OF THE CENSUS, BOUNDARY AND ANNEXATION SURVEY 1970-1973, at 63 (1975). An addition of this population to the suburbs rather than the city would have left the city losing population and the suburbs gaining it. This result is consistent with the other data presented in the table.

$\dagger$ Population estimates for San Antonio are based on 1970 census figures. See JEC PRINT 12 (Table 1).

SOURCES:

a Derived from Sales Management, Inc., 1975 Survey of Buying Power, Section 
The current situation is suggested by Table 1 . During the early seventies, over one-half of the twenty-nine largest metropolitan areas in the United States experienced net emigration. ${ }^{12}$ In other words, between 1970 and 1974, there were actually more people leaving these metropolitan areas than moving into them. As might be expected, these declining inetropolitan areas are generally older and located in the northern industrial tier. With the exception of Memphis, which was able to expand through annexation during the period examined, ${ }^{13}$ every central city in a declining metropolitan area was also experiencing a loss of central city population. ${ }^{14}$ These cities were affected by two trends: emigration from the central cities to their suburbs and migration between metropolitan areas.

A critical issue for the declining central city is whether it can remain the center of a functional economic unit. Even where central city growth has ended, it may be possible for a city to remain vital if it is

annually in the Northeast and 11.1 percent in the Midwest while net white emigration was 1.3 percent and 2.6 percent respectively. Havemann, Stanfield \& Peirce, Federal Spending: The North's Loss Is the Sunbelt's Gain, 8 NAT'L J. 878, 888 (June 26, 1976). Since 1970, however, black immigration to the Northeast has been less than white emigration. 1976 REPORT ON NATIONAL GRowth AND DEvelopMENT 25. As a result, for the first time since 1940, the Northeast is experiencing a net loss through migration. Id.

12. Net migration is that part of the change in a city's population which is not attributable to the natural population increase. See U.S. Bureau of THE CENSUS, CuRrent Population Reports: Estimates and Projections, Series P-25, No. 618 at 24 n.1 (January, 1976). It focuses on movements of people by removing from the calculation gains from births and losses due to deaths.

In the short run, net migration is the best indicator of population trends in a metropolitan area. By netting out births and deaths, this statistic eliminates changes in numbers of the very young and very old and reveals shifts in the work force more clearly than do raw population statistics.

13. See note * to Table 1 supra.

14. Since birth rates normally exceed death rates, negative population trends are generally indicative of net migration trends which are even more negative. Unfortunately, central city net migration statistics for the 1970 s are not yet available.

D (1975) (12/31/74 population estimates); SALES MANAGEMENT, INC., 1971 SuRveX OF BuYing Power, Section D (1971) (12/31/70 population estimates).

b Derived from Sales Management, Inc., 1975 Survey of Buying Power, Section D (1975) (12/31/74 city population estimates); SALES MANAGEMENT, INC., 1971 SuRVEY OF BUYING POWER, Section D (1971) (12/31/70 city population estimates); U.S. Bureau of THE CEnsus, CuRRent Population Reports: Population Estimates and Projectrons, Series P-25, No. 618, Table 1 (January, 1976) ("Estimates of the Population of Metropolitan Areas, 1973 and 1974, and Components of Change since 1970") (SMSA populations: 1970 census, 1974 (provisional)).

c, d Derived from U.S. Bureau of the Census, Current Population Reports: Population Estimates aNd Projections, Series P-25, No. 618, Table 1 (January, 1976) ("Estimates of the Population of Metropolitan Areas, 1973 and 1974, and Components of Change since 1970") (percent change in population and percent net migration 1970 to 1974 ). 
part of a broader metropolitan region which has the resources needed to support services in the region. The key to the maintenance of the metropolitan resource base is the suburbs. In such metropolitan areas as New York, Los Angeles, Seattle, Pittsburgh and Buffalo, it may be extremely difficult for the central cities to attract and develop the new revenue sources needed to support present levels of services. The fiscal situation is substantially more promising where the suburbs are growing. As Table 1 indicates, overall emigration tends to be less severe in metropolitan areas with growing suburbs. Even where suburban growth is not as rapid as central city decline, it appears likely that land values will remain more stable and that revenue sources will remain more constant in the metropolitan area with growing suburbs. ${ }^{15}$

In several declining central cities-New Orleans, Baltimore, Atlanta and Denver-suburban growth is actually so great that the metropolitan area is growing. If these cities could expand their boundaries or begin to attract would-be suburbanites into the central city, the central city might actually be able to grow. ${ }^{16}$

Only one-third of the central cities examined actually experienced an absolute growth in population between 1970 and 1974 . These growing cities tend to be the centers of relatively young, rapidly growing metropolitan areas. Central city growth has been generally limited to the younger cities ${ }^{17}$ of the South and Southwest ${ }^{18}$ and has been largely restricted to municipalities which had extensive geographic areas to begin with ${ }^{10}$ or have managed to annex adjacent territory.

15. See notes 121-26 infra and accompanying text.

16. The extent of Baltimore's central city population loss suggests that neither of these alternatives may be available there. The suburban growth which Baltimore is currently experiencing appears to be the result of the increasing dispersion of federal government employees who work in or around Washington, D.C. It is unlikely that the focus of these individuals' economic activity is Baltimore. See generally U.S. BUREAU oF the Census, Current Population Reports: Estimates and Projections, Series P25, No. 618, at 6, 23 (January, 1976) (figures for Washington and Baltimore Standard Metropolitan Statistical Areas (SMSAs) in Table 1).

17. Except for Memphis and Columbus (both seventy years old), which were able to expand by annexation in the early 1970s, see JEC PRINT 12 (Table 1), every growing central city listed in Table 1 of the text is less than fifty years old. See Peterson 76 (Table 13).

18. See Table 1 supra. See 1976 Report on National Growth and DevelopMENT 29 (Figure II-6).

19. Jacksonville, for example. grew in population even though it did not undertake any annexations during this period. In 1970, however, it had the lowest population density of any city in the country with population over $500,000-$ only 690 people per square mile. The next lowest density in a city of comparable size was Kansas City, Missouri, with 1,603 people per square mile. See Statistical AbStRact of the United StATES 1973, at 22-23 (Table 23). 
The capacity to annex has been critical to the continued growth that characterizes our fiscally strong urban areas. Of the fourteen cities with populations of 500,000 or more whose population consistently declined between 1960 and 1973, not a single one was able to annex a significant populated area. ${ }^{20}$ Yet during the same period, most of the cities which continued to grow had at least one and often two annexations resulting in 10 to 20 percent gains in central city population. ${ }^{21}$ Annexation has therefore accounted for almost all of the population growth experienced by most growing central cities.

TABLE 2

Annexations in Growing Cities 1970-1973

\begin{tabular}{|c|c|c|c|}
\hline $\begin{array}{l}\text { Growing Central } \\
\text { Cities }\end{array}$ & $\begin{array}{l}\text { \% Increase } \\
\text { in Territory } \\
\text { from } \\
\text { Annexation } \\
1970-1973 \\
\end{array}$ & $\begin{array}{l}\% \text {. Increase } \\
\text { in Population } \\
\text { from } \\
\text { Annexation } \\
1970-1973 \\
\end{array}$ & $\begin{array}{l}\text { Increase in Population due } \\
\text { to Annexation as a Percent } \\
\text { of Total Increase in Central } \\
\text { City Population, 1970-1973 }\end{array}$ \\
\hline Memphis & 19.9 & 21.9 & $390.0^{*}$ \\
\hline Dallas & 2.0 & 1.3 & $\dagger$ \\
\hline Columbus & 16.9 & 4.9 & $263.0^{*}$ \\
\hline Honolulu & - & - & 一 \\
\hline Jacksünville & - & - & - \\
\hline San Antonio & 37.9 & 2.0 & 30.2 \\
\hline San Diego & 1.9 & 1.4 & 16.5 \\
\hline Houston & 14.9 & ** & ** \\
\hline Phoenix & 8.6 & 11.0 & $129.0 *$ \\
\hline
\end{tabular}

* Figures over 100 percent reflect the fact that major annexations were undertaken during a period when population was otherwise declining.

$\dagger$ Despite the annexation, Dallas lost population during this period.

- No annexation.

** Data not available.

SOURCES: JEC PRINT 12 (Table 1); U.S. Bureau of the Census, Boundary aNd ANNEXATION SuRveY 1970-1973, Table 2 (1975).

A fairly strong pattern thus emerges. In all but a handful of metropolitan areas, the suburbs have continued to grow. The majority of central cities, however, are losing population from their core and are unable to recapture this population because of barriers to annexation.

20. Compare Peterson 76 with JEC PRINT 12. There were only three annexations by cities with declining populations during this period: Los Angeles added 10,293 and Chicago added 4,737 to their populations of about 3 million. Dallas also annexed a 5.2 square mile area with a population of 11,336 to increase its population of 844,000 by 1.3 per cent. Id. See also P. Porter, The Recovery of American Cimes 176 (1976) (not a single one of the twelve SMSAs which had a population of over 2 million in 1970 had experienced an annexation by its central city in the previous ten years).

21. See JEC PrINT 12 (Table 1). See also Peterson 72: "As a group, the 13 cities that gained population in the 1960 s enlarged their geographical area by 77 percent over the decade as a result of annexation and consolidation." 
These population losses imply a variety of problems with regard to both expenditure and revenue levels. In the next three sections, some of these problems will be explored in an effort to outline the policy options for the decliming cities and the pitfalls which currently growing cities should attempt to avoid.

\section{EXPENDITURES}

During the past two decades, the public sector of our economy lias experienced tremendous growth. ${ }^{22}$ As part of this expansion, municipal expenditures have increased dramatically. While in fiscal 1963 American cities spent $\$ 17.8$ billion, ${ }^{23}$ the cities expended over $\$ 60.4$ billion in fiscal 1975..$^{24}$ In metropolitan areas of all sizes, per capita expenditures for local services more than doubled between fiscal 1966 and fiscal $1973 .{ }^{25}$

This rapid growth in the local government sector can be attributed to a variety of factors. ${ }^{26}$ Inflation and dramatic likes in fuel and construction costs have affected local governments just as they liave affected private citizens and businesses. Sophisticated new technologies and the ever-increasing magnitude and complexity of providing local government services have also increased personnel costs, as needs have developed for more highly trained and specialized municipal employees. ${ }^{27}$

A third factor which has been generally assuined to have contributed to higher levels of municipal expenditures has been the availability of state and federal cost-sharing programs. It has been estimated that these programs induce additional city expenditures at a rate of about 40 percent for revenue-sharing funds and as high as 90 percent for categorical funds. ${ }^{28}$ The high concentration in the central cities of low-income

22. See, e.g., 1976 Report on National Growth ANd Development 44. Between 1954 and 1974, public expenditures nearly quintupled, increasing by 373.6 percent. The share of the gross national product for which they accounted rose from 27.2 percent in 1954 to 35.6 percent in 1974 . Public employment increased substantially during this period; in the last 15 years, one out of every three new jobs has been in the public sector.

23. U.S. Bureau of the Census, City Government Finances in 1964-65, Table 1 (1966).

24. U.S. Bureau of the Census, City Government Finances in 1974-75, Table 1 (1976).

25. See T. Muller, Growing and Declining Urban Areas: a Fiscal Comparison 13 (rev. ed. 1976).

26. See generally 1976 Report on National Growth and Development $45-47$.

27. See id. at 46.

28. Gramlich \& Galper, State and Local Fiscal Behavior and Federal Grant Policy, 1973 BROORINGS PAPERS ON ECONGMIC ACTIVITY 15. 
groups who can benefit from categoric assistance ${ }^{29}$ and other state and federal programs is a significant force in the high expenditures of the older declining cities.

The most important factor contributing to the growing costs of municipal services has been the escalating cost of public sector labor. The high labor-intensity of government services $^{30}$ makes the public sector extremely vulnerable to inflationary pressures, and the recent escalation of the cost of living has combimed with the power of public employee unions to make the increases in public sector labor costs particularly dramatic. ${ }^{31}$ Between 1970 and 1975 alone, average monthly wages (October payroll sample) for noninstructional municipal workers increased by 42.6 percent. $^{32}$

The upward pressures on municipal expenditures have been particularly acute in the older cities with declining populations. ${ }^{33}$ Cities facing declining populations spend more per capita, have more employees, and pay higher municipal wages than do cities with continued growth. ${ }^{34}$ In part, this problem comes from the lag effect which occurs when the city adds or eliminates service personnel. ${ }^{35}$ As a city grows, its ability to provide services lags behind the demand for those services. As a city matures, the number of service personnel per capita catches up with the demand for services. And as city population and the demand for services decline, the level of service personnel tends to remain at the

29. See Reischauer, The Federal Government's Role in Relieving Cities of the Fiscal Burdens of Concentrations of Low-Income Persons,' 29 NAT'L TAX J. 293, 295 (1976). In one-third of the SMSAs where the central city population has declined consistently between 1960 and 1973 , over 15 percent of the central county population was receiving welfare payments. See Peterson 76. While only small portions of welfare payments are financed locally (the exceptions being New York City, San Francisco, Denver, Philadelphia and Baltimore, all of which have no overlying county government), Reischauer, supra, at 300 , these welfare recipients are also dependent on other state and local federal programs to which local governments do contribute in varying degrees.

30. See 1976 Report on National Growth and DeVelopment 46: "70 to 80 percent of the budget for a typical city goes for wages, salaries, and fringe benefits."

31. See Peterson 106-12.

32. During this same period, the average October earnings of full-time instructional employees increased 31.7 percent. U.S. BuREAU of THE CeNSUS, CitY EMPLOYMENT IN 1975, at 1 (1976).

33. For the most comprehensive and recent works discussing this phenomenon, see T. MulleR, supra note 25 , and Peterson (both authors are from the Urban Institute).

34. In 1973 , for example, for cities with populations of more than 500,000 , the seven growing cities had only 58 percent of the per capita expenditure level of the fourteen cities that had a long history of decline. In addition, the growing cities had only 68 percent of the work force of the declining cities and the median age of their populations was only 85 percent of their declining counterparts. See Peterson 76-77.

35. See T. MULLER, supra note 25 , at 42 . 
level that had already been reached. However, some declining cities have managed to pare down their work forces substantially. ${ }^{36}$

Another factor contributing to higher expenditures in declining cities is their older pliysical plants, which are even more labor-imtensive and require more maintenance than do those of the newer cities. But perhaps the most fundamental reason is the nature of the population of the older cities. There simply are more persons in those cities who consume high levels of services without contributing much in the way of income-more aged, more unemployable adults, more female-headed louseholds with small cliildren. ${ }^{37}$

All of these conditions lielp to account for the increased per capita expenditures by the mature or declining cities, but they do little to explain the higher wages of municipal employees in those cities. Two factors appear to contribute to these ligher wages: first, the fact that mature and declining cities liave higher costs of living and higher private sector wages, and second, that employees in these cities frequently have stronger unions which wim inore favorable contract settlements. In addition, the higher wage costs are accompanied by mucl higher fringe benefit costs, particularly pension costs. ${ }^{38}$ This is attributable both to the higher municipal wages in these cities and to the delayed nature of municipal pension costs. Since there is a natural lag in the pension contribution for growing work forces, the younger and growing city will lave considerably lower pension costs than a city with an older work force, more retirees, and an older pension plan.

Yet even these factors do not explain the very ligh pension benefit levels enjoyed by municipal workers relative to workers in the private sector. This is better explained by the umique features of retirement benefits for policemen and firenien, ${ }^{30}$ the traditional concept of a public pension as compensation for a lower public wage, and the lack of

36. Pittsburgh, Cleveland and Memphis are the leading examples, each having cut its city work force by about 10 percent between 1970 and 1974. See JEC PRINT 23 (Table V).

37. See generally Reischauer, supra note 29.

38. While New York presents an extreme example, its high pension costs are indicative of the magnitude of the problem. The cost of pension plans in private industry is usually between 5 and 12 percent of payroll. The cost of New York City's retirement plans is over 30 percent of payroll. Thomas, Analysis of Pension Costs for Municipalities, 29 NaT'L Tax J. 234, 237 (1976).

39. In many cities, there has been a "longstanding practice of providing one-half of pay pensions at very early ages to policemen and firemen who have rendered 20 to 25 years of service . . ." Jump, Compensating City Government Employees: Pension Benefit Objectives, Cost Measurement, and Financing, 29 NAT'L TAX J. 240, 248 (1976). The cost of some police and fire department pension plans is close to 50 percent of payroll. Id. 
budget discipline on negotiated pension settlements because the higher costs are not felt immediately but come in later years. ${ }^{40}$

While choices about the quantity of services to be provided will be important, some of the most basic decisions facing the cities in the next few years will therefore involve service costs, which are largely independent of the level of services being provided. Since perhaps the most significant of these decisions will involve the pension cost component of wages, some of the questions which arise in connection with pension plans require fuller discussion.

\section{A. Pension Issues}

Some of the major issues with regard to public employee pensions today are:

(1) Level of benefits relative to public employee wages and relative to private sector benefits;

(2) Benefits for public safety officers, particularly the age at retirement and level of benefits relative to expected benefits earned from second careers;

(3) Tying benefit payments to wage levels or cost of living factors;

(4) Funding of pension commitments: the extent to which a city sets aside funds for future benefit payments as opposed to paying these benefits out of current revenues;

(5) Whether cities should be allowed to borrow from their own employees' pension funds;

(6) The role of Social Security benefits and the financial pressures caused by increasing payroll tax rates.

The problem with benefit levels has arisen as a corollary to the inflation of public employee wages. When these wages were well below those of the private sector, pensions with high benefit levels were considered to be only a fair reward for long service.11 However, now that public wages have more than caught up with private sector wages, ${ }^{42}$

40. Given the deferred nature of the pension obligation, a jurisdiction may avoid paying for some or even all of the accruing benefits until an employee retires and becomes eligible to collect. When such practices are followed, cost allocations are distorted over time as is the distribution of the cost burden among different generations of taxpayers.' Moreover, the stage may be set for sudden and catastrophic increases in current operating costs when the workforce matures and large waves of employees reach retirement age. Id. at 251.

41. See Sulley, supra note 9, at 391-92.

42. Peterson 107; see 1 U.S. ADVISORY COMMISSION ON INTERGOVERNMENTAL Relations, Significant Features of Fiscal Federalism: Trends 61 (Table XXIII)(1976). State and local employees now have annual earnings that are almost 4 percent above the national average whereas eighteen years ago they were 7.5 percent 
the accompanying benefit levels appear to be generally excessive and particularly so for the older declining cities. ${ }^{43}$

However, changes in pension benefit levels relative to wages can only occur over an extended period as future wage increases are negotiated. The policy choice that has the most immediate impact on the cash flow commitments of cities is the basic decision about funding of benefit commitments. Almost all plans have some degree of advance funding, and the practice has been growing. The ratio of incoming revenue to benefit payments is currently around 2.6 to 1 for public employee plans. More importantly, assets are now about eighteen times the annual benefit payments, a ratio which is 50 percent higher than that of thirty years ago. ${ }^{44}$ Nevertheless, the funds that are being set aside today will still not be sufficient to pay fully for the generous future retirement benefits that have already been promised. In actuarial language, the pension plans are not "fully funded." 45

Only one state, Massachusetts, has adopted an explicit policy of not funding any benefits in advance and operating on a pay-as-you-go basis. ${ }^{40}$ The advocates of pay-as-you-go point to the Social Security system as a model. In that system, the ability of the federal government to tax is the ultimate guarantee that future benefits will be paid. The question in adopting this policy for cities is whether or not the city's future ability to raise revenues is a sufficient guarantee of pension promises. There now exists a national policy, embodied in the Employee Retirement Income Security Act of 1974 (ERISA), ${ }^{47}$ which requires pension obligations of private employers to be funded in advance. At

below the national average. See Sunley, supra note 9, at 380 (Table 9-5). But see Kalman, Comment, 27 NAT'L TAX J. 491 (1974) (suggesting that such figures are misleading).

43. Although the data to make comprehensive comparisons of public and private benefit levels are not available, Tilove did compare average benefit levels for "typical" employees in New York State. Typical employees are those who may retire at age sixty after thirty years of service on a pension of at least 50 per cent of average pay for the last five years of service, and who are covered by Social Security. R. TILOVE, Public Employees Pension Funds 9 (1976). Tilove found that public employee benefits (exclusive of Social Security) tended to be $11 / 2$ to two times higher than those paid to private employees at comparable salary levels. Id. at 58-59 (Table 3.3). Even with Social Security included, the public benefits were substantially higher at all levels. Id. Exclusive of Social Security, the public benefits ranged as high as 49 percent of final salary. Id. But see Kalman, supra note 42.

44. R. TILOVE, supra note 43, at 172 .

45. For an overview of the economics of pension funding, see Bahl \& Jump, The Budgetary Implications of Rising Employee Retirements System Costs, 27 NAT'L TAX J. 479 (1974); Jump, supra note 39; Thomas, supra note 38.

46. R. TILOVE, supra note 43, at 131.

47. 29 U.S.C. $\S \S 1001$ et. seq., (Supp. IV, 1974). 
the time of the passage of that act, Congress debated whether public employee plans should be subject to the same requirement. ${ }^{48}$ Fearing that such a requirement might place a large financial burden on cities that were already hard-pressed, Congress chose not to apply ERISA funding requirements to the public sector. ${ }^{49}$

Adopting a relatively full measure of advance funding is much easier for a growing city than for a mature or declining city. In comparison to a mature city with a more level work force, a growing city has fewer employees with long years of service and fewer retirees or employees close to retirement relative to the overall size of its work force. These older employees are the most expensive in terms of pension contributions. While advance funding is probably a moot policy issue for the hard-pressed declining city (since a move to advance funding only makes a bad cash flow situation that much worse), a growing city that is planning for its own maturity can make relatively modest contributions today which would do much to avoid the dramatic ballooning of retirement costs that coines with a maturing pay-as-you-go system. $^{50}$

The level of funding is extremely important to the security of an einployee's pension. To the extent that a plan is funded, the employee's pension is secure. The assets which will be used to pay the pensioner upon retireinent have already been paid out by the government and are in the possession of an independent retirement fund. To the extent that the plan is not funded, however, the fund and its meinbers are in no better position to force payment than the city's other creditors, and, where a city is unwilling or unable to pay its obligations, it may be extremely difficult for creditors to force payment. ${ }^{51}$ Where a municipal pension plan is not fully funded, the pension plan should, at the very least, require the government to pledge its full faith and credit toward payment. This pledge should give the fund the highest possible preferred status anong the city's creditors. ${ }^{52}$ An effort inight also be made to

48. See S. REP. No. 93-1090, 93d Cong., 2d Sess. 291 (1974)(summarizing previous versions of ERISA and the final compromise).

49. See 29 U.S.C. $\$ 1003$ (b) (1) (Supp. IV, 1974).

50. It should also be pointed out that these decisions about contribution levels for a city's employees may be out of the hands of: municipal officials. This is because many local employees are members of state-vide systems which determine their own funding practices and in turn levy assessments on local governments.

51. See Note, Creditors' Remedies in Municipal Default, 1976 Duke L.I. 1363.

52. See Flushing Nat'l Bank v. Municipal Assistance Corp., 40 N.Y.2d 731, 358 N.E.2d 848, 390 N.Y.S.2d 22 (1976) (Emergency Moratorium Act postponing claims of holders of "full faith and credit" bonds violates state constitution). It seems likely that a pension fund which has been pledged the city's full faith and credit will be given 
include an explicit declaration in the pension agreement that pension fund payments are to be treated as operational expenses in the event of bankruptcy. Such a provision may allow the government to continue to inake pension payments as part of its ongoing operation during a period of financial reorganization..$^{53}$

A second problem arises with respect to the city's ability to contimue to benefit from capital it has paid over to its employees' pension fund. Even though most systems are nowhere near fully funded, they still possess sizeable assets. The New York City situation has raised the issue of the propriety of using such assets to aid the city. After New York's Municipal Assistance Corporation found itself unable to market its securities in the fall of 1975 , the city arranged to sell over $\$ 2.5$ billion in serial bonds to its employees' retirement funds. ${ }^{54}$ Such transactions call into question the whole rationale for requiring advance funding at all. If the city makes a contribution with one hand and borrows it back with the other, it is a "wash" transaction even though a liability exists on the city's books and an asset exists on the books of the pension fund. These funds thus begin to look much more like the "surplus" account of the municipality than a trusteed pension fund.

On the other hand, the use of such funds as an emergency measure in a nunicipal liquidity crisis may have some real justification when it is realized that the major prospective claimants (or owners) of those funds are the current employees of the city. These employees have inuch to lose (such as pay checks) if the city finds itself unable to meet its current obligations.

Fortunately, the potential for government use of pension plan assets in periods of finanical distress is narrowly limited by the provisions of the Internal Revenue Code. Although local governments are themselves tax-exempt entities ${ }^{55}$ which derive no added advantage from

preferred status over bondholders in a court of equity. Unlike the bondholder who extracts a risk premium as part of the city's interest payments, an employee does not contemplate any danger that his pension will not be paid. See Note, supra note 51, at 1372.

53. See Amendments to Chapter IX of the Bankruptcy Act, 11 U.S.C.A. $\$ 409$ (Supp. 2, Part 1, 1976). See generally King, Municipal Insolvency: Chapter IX, Old and New: Chapter IX Rules, 50 AM. BankR. L.J. 55, 63 (1976); King, Municipal Insolvency: The New Chapter IX of the Bankruptcy Act, 1976 DukE L.J. 1157.

Such an arrangement may be unnecessary to protect continued payments which are required according to provisions of the employees' wage contracts. However, explicit provision may be necessary to give priority to payments to retired employees. It seems reasonable to argue that such payments are necessary to maintain municipal operations since, if they are cut off, municipal employees are likely to strike.

54. H.R. REP. No. 94-851, 94th Cong., 2d Sess. 4 (1976).

55. INT. REV. CODE OF 1954, § 115. 
maintaining the tax-exempt status of a pension plan, important tax advantages are available to employee members of pension plans that qualify for tax-exempt status under the Code. Employees covered by qualified plans may defer payment of taxes on employer contributions made on their behalf until they actually begin to receive benefits. ${ }^{56}$ If a plan is disqualified, the employees lose this important tax advantage and will be taxed on their interests in the plan as they vest. ${ }^{57}$ Qualified plans also provide certam special allowances for income averaging and estate and gift tax benefits which are not available to members of unqualified plans. ${ }^{58}$ The value of these tax benefits to government employees is an important factor in encouraging governmental employers to design qualified plans. ${ }^{59}$

Where a qualified plan exists, all of the fund's assets must be used for the exclusive benefit of employees and their beneficiaries, ${ }^{60}$ and the trust is prohibited from lending any part of its income or corpus to any party inaking substantial contributions to the plan or to the plan's creator without adequate security and an adequate rate of interest. ${ }^{01}$ Where the plan violates the "exclusive benefit rule" or enters into a "prohibited transaction," the entire plan loses its tax-exempt status. ${ }^{62}$

An agreement by a qualified plan to purchase or retain securities of a governmental unit during a period of financial stress will necessarily endanger the tax-exeinpt status of the plan. ${ }^{63}$ If the agreement is designed to improve the fiscal status of the city, the transaction will not be for the exclusive benefit of the meinbers of the retirement plan. Even if it is emphasized that the employees may lose their jobs should the city collapse, it is unlikely that the exclusive benefit rule can be satisfied; such a transaction would benefit many others who have no interest in

56. Id. $\$ 402$ (b); see H.R. ReP. No. 94-851, 94th Cong., 2d Sess. 5 (1976); STAFF of the JoINT Comm. on Internat Revenue TaXation, 94TH CONG., 2D Sess., Application of Pension Provisions to New York City's financial Problems 2-3 (Comm. Print 1976).

57. INT. Rev. Code of 1954, $\$ 402$ (b); see H.R. REP. No. 94-851, 94th Cong., 2d Sess. 5 (1976).

58. See H.R. REP. No. 94-851, 94th Cong., 2 d Sess. 5 (1976).

59. See id.

60. INT. REv. CODE OF 1954, $\$ 401$ (a).

61. Id. $\S 503(1)(B)(1)$. See also id. $\S 402$ (a)(1). The reference to other persons making substantial contributions may be inportant in the government context. Where several units of government make contributions to a plan, they may all be covered by the prohibited transaction provisions of the Internal Revenue Code.

62. Compare id. $\$ 401$ (a) (exclusive benefit rule) with id. $\$ 503(1)$ (B) (prohibited transactions); see H.R. REP. No. 94-851, 94th Cong., 2d Sess. 5-6 (1976).

63. See H.R. REP. No. 94-851, 94th Cong., 2d Sess. 6 (1976). 
the plan and would endanger vested interests of retired employees who may no longer have any direct financial stake in the operation of the city.

More importantly, it will probably be extremely difficult for a city to offer the kind of security which would be needed for a plan to avoid disqualification under the prohibited transaction rule in inaking a loan to its creator. The Internal Revenue Service has "taken the position that the pledge of an employer's general assets does not provide adequate security for purposes of the prohibited transaction rules," ${ }^{\prime 4}$ and the amorphous nature of the obligation which underlies the pledge of a municipality's full faitl and credit ${ }^{65}$ makes a mumicipal security substantially less secure than a pledge of the general assets of a private sector employer. While it may be possible to solve the security problem by a loan guarantee froin the state or preferably the federal government, ${ }^{66}$ it seems clear that an arrangement for a municipal employee pension plan to invest in its employer city will be difficult to consummate unless members of the plan are willing to lose the advantages of their taxexempt status. Only federal legislation can protect the tax exemption of such funds. ${ }^{67}$

The pension systems in cities that are essentially on a pay-as-yougo basis are, in effect, making long-term loans to their cities. It would make little sense for such cities to begin substantial advance funding of their pension plans if their financial situation would require thein to turn around and borrow those funds back. However, there would be some advantage in this course; the current costs of pension benefits would have to be calculated and funds set aside (at least on the books). This could serve as a brake on excessively generous pension settlements since any increased commitments would show up as expenditures which were then offset by increased borrowing. The other alternative is to slow the unfunded pension liability directly and hope that such disclosure will itself be a sufficient constraint on the level of pension settlements.

64. Id., citing Rev. Rul. 70-131, 1970-1 Cum. BuLl. 135.

65. See generally Note, supra note 51.

66. The federal government is the preferable source since it, with its power to print money, is presumptively secure. State obligations may create the same collection problems as municipal obligations. Members of the House Ways and Means Committee, which reported the bill that ultimately exempted the New York transaction from the Internal Revenue Code's exclusive benefit and prohibited transaction provisions, questioned the capacity of that transaction to escape disqualification as a prohibited transaction, H.R. ReP. No. 94-851, 94th Cong., 2d Sess. 6-7 (1976), despite New York State's enaetment of legislation to indemnify the fund trustees against loss. Id. at 4.

67. See id. at 7 (this is what occurred in New York City); 90 Stat. 238 (1976). 


\section{B. Social Security}

Another significant issue facing local officials as they consider the means of controlling costs is the role played by Social Security. Local governments can participate in Social Security on a voluntary basis. ${ }^{68}$ Many local governments have taken advantage of this option. In the fourteen years from 1961 to 1975 , coverage of public einployees nearly tripled, froin 3 million to almost 9 million, so that about 70 percent of the state and local work force is now covered by Social Security. ${ }^{60}$ Once a local government has joined the Social Security systein, it can exercise a one-time option to get out again. This decision does not need to be approved by its employees. ${ }^{70}$ Because of the general financial pressures faced by local governments and because of the steady increase in Social Security payroll tax rates, many local governments have begun to consider exercising their option to drop out of the Social Security systein. ${ }^{71}$

There are basically two perspectives from which to confront the Social Security issue. One is the national policy perspective which focuses on the potential impact of public employee withdrawals on the condition of the Social Security trust funds. Current estimates indicate that the recent proposed withdrawal of New York City einployees alone would have caused a $\$ 3.1$ billion loss in contributions between 1978 and 1982 without any concomitant reduction in the outflow of benefits, since the withdrawal would not affect those already entitled to benefits. ${ }^{72}$ Over the long run, there is concern that the system will be weakened both in terms of financial soundness and public support by government

68. 42 U.S.C. $\$ 418(A)(1)(1970)$.

69. Senate Special Comm. on aging, 94th Cong., 2d Sess., Termination of Social Security Coverage: The Impact on State and local Government EMPloyees 4-5 (Comm. Print 1976). See also Staff on the Subcomm. on Soctal Security of the House Comm. on Ways and Means, 94th Cong. 2d Sess., Background Material on Social Security Coverage of Governmental Employees aNd EMPLOYEeS OF NONPROFIT ORGANizations (Comm. Print 1976), in Hearings Before the Subcomm. on Social Security of the House Comm. on Ways and Means on Coverage and Termination of Coverage of Government and Nonprofit Organization Employees Under the Social Security System, 94th Cong., 2d Sess. 7 (1976).

70. See 42 U.S.C. $\$ 418(G)(1)$ (1970); Senate Special Comm. on AgIng, supra note 69 , at 4 .

71. To terminate its coverage by Social Security, a local government must give two years advance notice. 42 U.S.C. $\$ 418(G)(1)$ (1970). Until recently, 500,000 employees had been members of groups in eleven states that had termination notices pending. The largest group of these was 362,000 employees in New York City, SeNaTe Special Comm. on Aging, supra note 69, at 4-5; STAFF of THE Subcomm. on Social Security, supra note 69 , at 8 , which recently withdrew its termination notice.

72. Staff of the Subcomm. on Social SeCURITY, supra note 69, at 9. See note 71 supra. 
employer withdrawals. First, there is a general feeling that public employees (and their employers) currently put more into the systein than they take out, so that the federal governinent has a great financial incentive to keep state and local governments in the system. Second, although that portion of the public sector which participates in Social Security generally makes the system fiscally stronger, windfall benefits may accrue to employees of non-participating governments who spend enough time in the private sector to qualify for minimum Social Security protection. ${ }^{73}$ Finally, to the extent that Social Security is viewed as a national insurance program, there is a concern that inadequate protection will be given to public employees under other plans. ${ }^{74}$

The other perspective is that of the local government itself. If the local government is financially hard-pressed, Social Security termination can provide some immediate fiscal relief. ${ }^{75}$ On the other hand, the local government may take the longer view and consider the question of whether or not Social Security is a "good buy" in terms of the benefits received for the taxcs paid. Even in this case, the local government inay decide that it is advantageous to terminate its participation if only the impact on current employees is considered, since many of these employees will have already earned entitlement to basic Social Security benefits and future benefit increases for them may be small relative to the taxes to be paid. Finally, even if the local government finds the benefits to be a "good buy" for its current or future employees, it may still decide that the particular types of benefits offered by Social Security are not the ones that it wishes to purchase for its employees. The government may prefer inore generous retirement benefits and less disability benefits, for example. In any case, there will continue to be increased pressures in the near future for local governments to consider withdrawal, ${ }^{70}$ and this trend will undoubtedly stimulate serious discussions

73. Staff of The Subcomm. on Social Security, supra note 69, at 10. Windfalls occur because those with lowest earnings and therefore lowest contributions receive back in the form of benefits a much higher percentage of their contributions than do those in higher wage brackets.

74. Id. at 8-10; see Myers, Should State and Local Governments Desert the Social Security Ship?, 37 Tax Rev. 37 (1976). See generally Senate Special Comm. on AGING, supra note 69 , at 9-27.

75. New York City, for example, would avoid payment of $\$ 250$ million per year in social security payroll taxes if it were to terminate. Senate Special CoMm. on Aging, supra note 69 , at 8.

76. In addition to the financial pressures on governments, employee pressure for more take-home pay, the well-publicized fears that Social Security taxes will continue to rise or that the system will go broke, and the belief of many employees that they will be eligible for benefits in any event, have all contributed to the recent increase in terminations. See Senate Spectal Comm. on Aging, supra note 69, at 6-8. 
in Congress concerning modification of the Social Security Act's state and local government termination provisions.

Indeed, Congress has already begun such a reappraisal. The major alternatives currently being discussed include:

(1) Making coverage compulsory for all state and local government employees;

(2) Repealing the current termination provisions so that governments which are currently part of the system cannot quit;

(3) Coupling compulsory coverage with treatment of public employees as "self-employed" persons for purposes of the Act;

(4) Making termination conditions more restrictive by requiring employee consent or by freezing benefits. ${ }^{77}$

From the perspective of federal policy, the first alternative, compulsory coverage, is clearly the preferred option. It remedies the termination problem, eliminates wimdfalls, and helps to fill in gaps in protection of those who move between jobs which are or are not covered by Social Security. ${ }^{78}$

Unfortunately, there may be significant constitutional impediments to federal legislation requiring state and local government participation in the Social Security systein. Authority for the payroll tax on which the Social Security system is based is derived from the taxing power in article I of the Constitution. ${ }^{79}$ Public employees have historically been exempted from the mandatory coverage provisions of the Social Security Act because of fear that any general levy of the employer tax on state and local governments would be unconstitutional. ${ }^{80}$ While there has been some feeling in recent years that this problem could be overcome under the present state of the law, any doubts that a mandatory tax on state and local government would encounter constitutional obstacles were clearly dispelled by the recent Supreme Court decision in National League of Cities v. Usery. ${ }^{81}$ In Usery, the Supreme Court struck down provisions of the Fair Labor Standards Act (FLSA) ${ }^{82}$ that required

77. Senate Special Comm. on Aging, supra note 69, at 22-27; StafF of the Subcomm. on Social Security, supra note 69, at 11-15.

78. Staff of The Subcomm. on Social Security, supra note 69, at 11.

79. U.S. ConsT. art. I, $\$ 8$, cl. 1 .

80. See, e.g., Staff of The Subcomm. on Social Security, supra note 69, at 5; Myers, supra note 74, at 38.

81. 426 U.S. 833 (1976). See generally Comment, Federal Regulation of Municipal Securities: A Constitutional and Statutory Analysis, 1976 DUKE L.J. 1261.

82. 29 U.S.C.A. $\$ \S 203(S)(5),(X)$ (Supp. 1976). The Court cited the rarely invoked tenth amendment as support for its holding that, in light of the constitutional policies of federalism and state sovereignty, some provisions of the FLSA extended beyond the power granted to Congress in the commerce clause. 426 U.S. at 842-45. 
state and local governments to pay their employees the mininum wage. ${ }^{83}$ Concluding that the imposition of minimum wage standards on local governments would interfere with the states' sovereignty by affecting service levels and employment decisions, ${ }^{84}$ the plurality held that Congress could not inpose the FLSA on the states since the concept of federalism embodied in the tenth amendinent prohibits the federal government from impairing "the States' freedom to structure integral operations in areas of traditional governmental functions." 85

While Usery is explicitly linited to the commerce clause, ${ }^{86}$ it seems clear that the reasoning in the case would also be applied to the taxing power. ${ }^{87}$ Such a result is particularly likely in light of the similarity between the effects of the ininimum wage standards struck down in Usery and those of the payroll tax which proponents of compulsory coverage would impose on state and local governments. At least in the short run, the effect of a payroll tax on public einployers would be the same as that of the minimum wage. Governmental units not presently participating in the Social Security systein would be deprived of funds which they would otherwise have been able to devote to services. Governments that are currently members of the system would be deprived of the opportunity to redesign their compensation packages in ways that would be cheaper for their communities or in ways they think would be more successful in attracting individuals into public service. This sane difficulty would arise if the federal government were to attempt to

U.S. CoNST. amend. $\mathrm{X}$ provides as follows: "The powers not delegated to the United States by the Constitution, nor prohibited by it to the States, are reserved to the States respectively, or to the people."

83. National League of Cities v. Usery, 426 U.S. 833, 849-52 (1976). For a description of the particular provisions of the FLSA which are affected by the decision, see id. at 835-40.

84. See id. at 844-48.

85. Id. at 851-52. The decision in Usery is explicitly applicable to local governmental units since, as their denomination "political subdivision" implies, these units derive their authority and power from their respective states. Id. at 855 n.20.

86. Id. at 852 n.17.

87. There is a tension in the plurality opinion on this point. While Justice Rehnquist specifically left open the question of the tenth amendment's effect on the spending power, $i d$., the reasoning of the decision relied heavily on earlier cases concerning the authority of Congress to impose taxes on the states. See id. at 842-45. However, the Court is presently in the process of giving increasing respect to "state rights" in a number of areas of the law. See, e.g., Paul v. Davis, 424 U.S. 693 (1976) (local police discretion). See generally Comment, Post-Younger Excesses in the Doctrine of Equitable Restraint: A Critical Analysis, 1976 DUKE L.J. 523. There is no reason to expect that this trend will not manifest itself in the tax area as well. As Justice Rehnquist explained in his opinion for the Usery plurality, the "Court has never doubted that there are limits upon the power of Congress to override state sovereignty, even when exercising its otherwise plenary powers to tax ..." 426 U.S. at 842 . 
eliminate provisions which presently allow governmental participants in the Social Security system to terminate.

It appears that compulsory coverage can be accomplished, Usery notwithstanding, by shifting Congress' focus from the employer to the employee. The tenth amendment should not be read to circumscribe the power of Congress to tax employees of other levels of government. It is now well established, for example, that the official salaries of all state employees, including governors, are subject to taxation by the federal government. ${ }^{88}$ There does not appear to be any constitutional reason why Congress could not require public employees to participate in the Social Security system, impose a payroll tax on the employee to fund the system, and require all governmental employers to make appropriate collections. Such a scheme could be enmeshed with the present system of income tax withholding, since it has previously been established that the federal government may require the states or their political subdivisions to withhold taxes from their employees. ${ }^{89}$

The critical issue is the level at which public employees should be taxed under a compulsory provision. Any attempt to require coverage that subjects only public employees to the employee payroll tax rate without exacting matching contributions from governmental employers would put an additional strain on the Social Security system which would have to be borne by other contributors. ${ }^{90}$ On the other hand, taxing public employees at a rate which would cover both the employer and employee contributions in the private sector would be seen as placing an unfair burden on public employees and could constitute an important deterrent to those considering public service. In fact, however, the effective burden of this tax does not depend on the sources from which it is collected. A payroll tax will impose the same burden on employees regardless of whether it is collected from the employer, from the employee, or partially from both..$^{31}$ This would argue for a requirement that a shift to an all-employee tax be accompanied by matching salary increases so that both the employee's after-tax salary and the government's payroll costs will remain unchanged. Unfortu-

88. E.g., Graves v. New York ex rel. O'Keefe, 306 U.S. 466 (1939). See also Sims v. United States, 359 U.S. 108 (1959).

89. Section 3402 of the Internal Revenue Code requires employers to withhold federal income taxes from wages paid employees. The term "employer," as defined in section 3401(d), has been construed to include the states and their agencies, instrumentalities and subdivisions. Treas. Reg. \& 31.3401(d)-1(d) (1957).

90. StafF of THe Subcomm. on Social Security, supra note 69, at 11.

91. See R. Musgrave \& P. Musgrave, Public Finance in Theory and Practice 410-13 (2d ed. 1976). 
nately, the reasoning of Usery would clearly preclude the federal government from imposing such a mandate on state and local governments. Even so, if a city's economic conditions do not change, market forces can be expected to force employee salaries to this level over time in any case. For employees of governments that are not currently participating in Social Security, any requirement of employee participation will impose a new tax burden along with the new expectation of benefits. In the long run, however, the market should function so that the burden on these employees will be the same whether the Social Security tax is assessed on the employee, employer, or shared between the two. Unfortunately, this fact is unlikely to be recognized by the employees who would see sizeable portions of their paychecks going to Social Security even after inarket forces begin to offset this burden.

The solution that has been proposed for this dilemma is to tax public einployees as if they were self-employed. ${ }^{92}$ This would expose the public workforce to a payroll tax rate that is higher than the employee rate but lower than the coinbined employer-employee rate of contribution found in the public sector. ${ }^{93}$ A similar approach is currently enployed with respect to participating members of several other vocations such as clergy and employees of foreign governnients where the federal government cannot tax the employer. ${ }^{94}$

The difficulty with the compulsory coverage/self-employed-rate approach lies in the anticipated response of state and local governnients. Compulsory employee participation would tend to induce governinental units to forgo participation in the Social Security system, since they would be able to avoid the cost of the eniployer contribution without jeopardizing their employees' protection. ${ }^{95}$ Unless market conditions or political considerations force participating localities to remain in the system, compulsory employee participation at a self-einployed rate is therefore likely to encourage governinent eniployer terminations. ${ }^{96}$ While retaining public employee contributors even at the self-employed rate will help the Social Security system to overcome its short-run

92. Staff of the Subcomm. on Social Security, supra note 69, at 12; see Senate Special Comm. on AgING, supra note 69, at 31-32.

93. Under the current private sector payment schedule, employers and employees each contribute amounts equal to 5.85 percent of the employee's earnings while the selfemployed pay 7.90 percent. Senate Special Comm. on Aging, supra note 69, at 31. See also StafF of the Subcomm. on Social SecurtTy, supra note 69, at 12.

94. StafF of the Subcomm, on Soctal SecurTty, supra note 69, at 12.

95. Id.

96. To some extent, this situation may be justified by the relief it affords the cities during the current period of financial strain. 
financial problems, the lower per capita contribution levels resulting from self-employed status may contribute to a serious problem in the long run. Unless municipal employees as a group in Social Security are at least self-supporting over the long term, there is no ultimate fiscal advantage to compulsory participation.

Nevertheless, it appears that compulsory coverage at the self-employed rate is superior to the proposals to modify the Social Security Act's state and local government termination provisions for several reasons. First, while modification may help to slow governmental terminations, none of the proposals will satisfactorily insure continuous coverage or eliminate windfalls for the numerous public einployees who are not currently im the system. Freezing benefit levels to deter terminations would be difficult to administer and, from a national viewpoint, would be counterproductive simce it could eventually leave many public employees with imadequate coverage. ${ }^{97}$ Proposals to condition termination on certification that benefit levels under a replacement plan would be comparable to those under Social Security or an approval of a majority of employees have similar shortcomings. ${ }^{98}$ Finally, there are some important legal questions concerning the ability of the federal government to unilaterally amend the termination provisions at all. ${ }^{99}$

\section{REVENUES}

Between 1962 and 1975, the non-capital general expenditures of American cities have increased by 376 percent. ${ }^{100}$ During the same period, general revenues from cities' own sources rose by only 289 percent. $^{101}$ In fiscal 1975 , American cities were spending over $\$ 11$ billion more on their current operations than they were raising from their own revenue sources. ${ }^{102}$

Whatever the reason for this dranatic increase in the expenditures for municipal services, it is quite clear that the cities are no longer financing their current service levels out of their own revenue sources.

97. Staff of The Subcomm. on Social Security, supra note 69, at 14.

98. See Senate Special Comm. on Aging, supra note 69, at 19-21 (suggesting that the employees' short-term interests in higher pay may make them insensitive to the longer range issues of retirement benefits).

99. Id. at 32; Staff of The Subcomm. on SOCIal Security, supra note 69, at 14.

100. Compare U.S. Bureau of the Census, CtTy Government Finances IN 197475, Table 1 (1976), with U.S. Bureau of the Census, City Government Finances in 1964-65, Table 1 (1966).

101. Id.

102. See U.S. Bureau of the Census, City Government Finances in 1974-75, Table 1 (1976). 

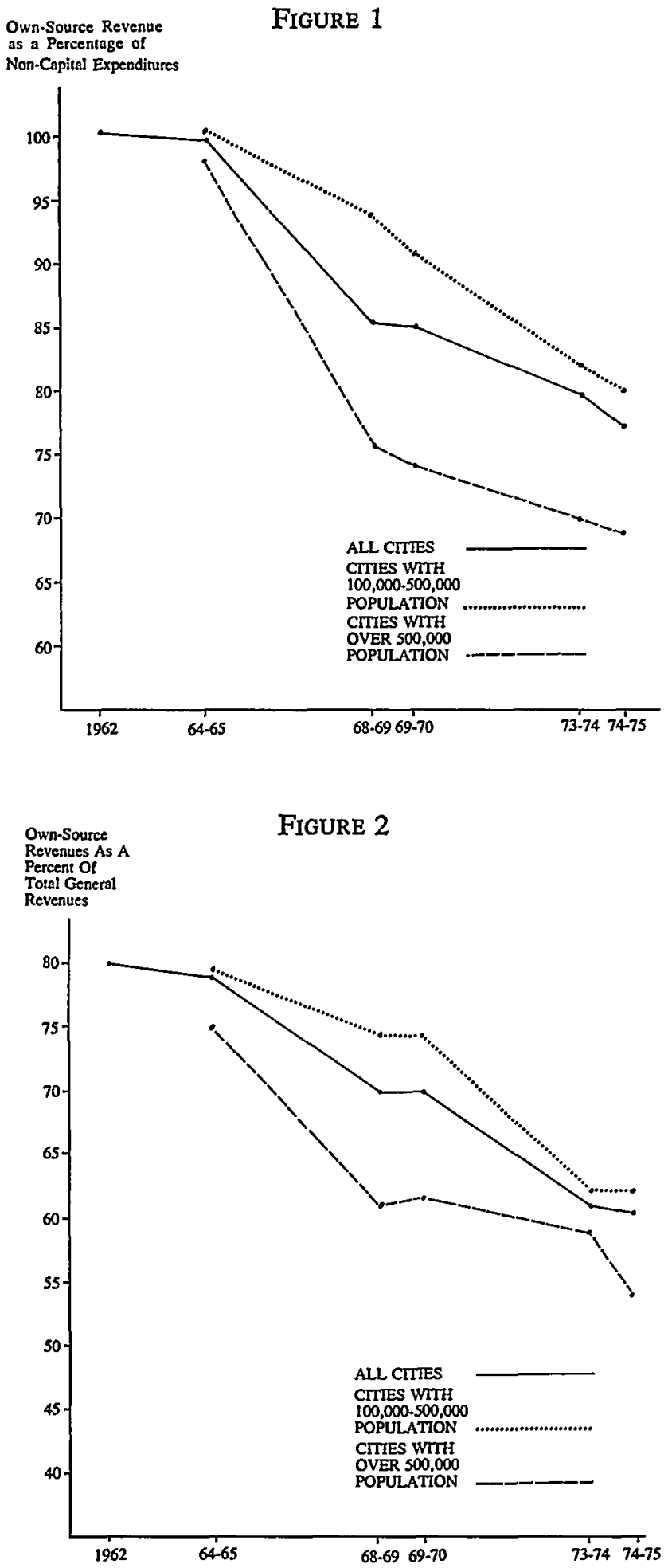
As Figure 1 illustrates, in the early 1960s cities of all sizes financed virtually all of their non-capital general expenditures from their own revenue sources.

Today, as Figure 2 indicates, the average city receives only 61 percent of its general revenues from its own resources. ${ }^{103}$ This phenomenon is closely related to urban size. The twenty-nine cities with populations of more than 500,000 obtained only 54 percent of their general revenues from their own sources in 1975, down from 63 percent in 1969 and from 78 percent as recently as $1965 .^{104}$

The inpact that this increasing reliance on outside aid has had on local tax burdens is suggested by the last two columns in Table 3 . Column 3 shows the ratio of the percentage change in intergovernmental aid to the percentage increase in own-source revenues for the period between fiscal years 1970 and 1975 . If both outside aid and ownsource revenues increased at the same rate over this period, the ratio shown in column 3 would be equal to one. This would mean that both outside aid and own-source revenues continued to comprise the same share of total general revenues in the two years exammed. If, on the other hand, outside aid grew twice as fast as own-source revenues (e.g., 100 percent and 50 percent respectively), then the ratio in column 3 would be equal to two. The ratios in this column are thus imdicative of the rate at which dependence on outside revenue sources has changed over the period. A ratio greater than one means that outside aid dependence has increased, and a ratio less than one means that this dependence has decreased. Column 4 shows the absolute increase in own-source revenues as a percentage of after-tax personal income which occurred between fiscal years 1970 and 1975. Although they do not take into account revenues that may be raised through special districts or other arrangements which do not run funds through city accounts, the figures in this column are suggestive of the effective tax burdens these cities are placing directly on their citizens.

In analyzing Table 3, one fact stands out: the large cities examined increased their outside revenue sources at an average of six times the rate at which they increased their own revenues from local sources. ${ }^{105}$ While this rate of mcrease varied widely from city to city, only three cities-San Francisco, Denver and Seattle-failed to increase outside aid more rapidly than own-source revenues over this period.

103. See id. Table 5 .

104. See Figure 2 of this text. The 78 percent derived from own-source revenues was nearly equal to the total non-capital expenditures of the cities in 1965. This is not surprising since most aid to cities at that time was for capital expenditures.

105. In Table 3, column 3, which reflects this rate, the average ratio is 5.96 . 


\section{TABLE 3}

Changes in Municipal Dependence on Intergovernmental Aid and Municipal Tax Burdens, 1970-1975

\begin{tabular}{|c|c|c|c|c|}
\hline & $\begin{array}{c}1975 \\
\text { Aid Dependencea }\end{array}$ & $\begin{array}{c}1975 \\
\text { Tax Burden }\end{array}$ & $\begin{array}{l}\text { Change in Aid } \\
\text { Relative to } \\
\text { Change in Own- } \\
\text { Source Revenues } \\
1970-1975 \text { c } \\
\end{array}$ & $\begin{array}{l}\text { Change in } \\
\text { Revenue } \\
\text { Burden } \\
1970-1975 d \\
\end{array}$ \\
\hline Baltimore & $64.2 \%$ & $10.05 \%$ & 2.97 & -.23 \\
\hline Buffalo & 59.7 & 6.65 & 2.92 & . $\quad 1.16$ \\
\hline Memphis & 58.8 & 3.80 & 2.31 & -.95 \\
\hline New York City & 52.7 & 14.26 & 1.78 & 3.01 \\
\hline Milwaukee & 50.1 & 3.85 & 2.74 & .08 \\
\hline Indianapolis & 42.9 & 3.29 & 9.81 & 1.05 \\
\hline Phoenix & 41.8 & 2.93 & 3.52 & -.04 \\
\hline Detroit & 40.2 & 5.81 & 4.21 & .42 \\
\hline Cincinnati & 37.8 & 11.72 & 2.05 & 3.03 \\
\hline Jacksonville & 37.8 & 4.88 & 12.83 & 1.41 \\
\hline New Orleans & 37.1 & 4.81 & 7.84 & -.25 \\
\hline Pittsburgh & 36.8 & 3.50 & 14.03 & -.53 \\
\hline Cleveland & 35.0 & 5.48 & 20.84 & .01 \\
\hline San Diego & 34.9 & 2.78 & 5.20 & -.34 \\
\hline San Francisco & 34.5 & 9.38 & .71 & -.34 \\
\hline Boston & 33.9 & 13.38 & 3.81 & -.11 \\
\hline Philadelphia & 32.3 & 6.80 & 8.73 & -.54 \\
\hline Chicago & 31.4 & 4.37 & 2.17 & .71 \\
\hline Denver & 31.1 & 7.39 & .95 & 1.66 \\
\hline Atlanta & 30.4 & 6.15 & 4.52 & 1.45 \\
\hline St. Louis & 28.9 & 7.94 & 12.38 & .46 \\
\hline San Antonio & 29.6 & 2.71 & 14.79 & -.36 \\
\hline Seattle & 28.1 & 4.05 & .52 & .70 \\
\hline Columbus & 28.0 & 3.75 & 1.57 & .47 \\
\hline Honolulu & 25.7 & 7.04 & 3.71 & -.29 \\
\hline Los Angeles & 24.8 & 4.18 & 2.60 & .48 \\
\hline Kansas City, Mo. & 24.1 & 6.13 & 5.56 & -.94 \\
\hline Houston & 16.0 & 3.32 & 8.90 & .36 \\
\hline Dallas & 14.2 & 3.83 & 8.44 & .34 \\
\hline
\end{tabular}

a Intergovernmental revenues divided by total general revenues.

b Own-source revenues divided by total after-tax personal income.

c Percentage change in aid divided by percentage change in own-source revenues. This figure indicates the rate of change in outside revenues relative to the rate of change of own-source revenues. A value equal to one indicates that aid grew at the same rate during the period examined as own-source revenues. income.

d Absolute increase in the ratio of own-source revenues to after-tax personal

SOURCES: Sales Management, Inc., 1976 Survey of Buying Power, Section D (1976) (1975 after-tax income); Sales MANAGEMENT, INC., 1971 SURVEY OF BUYING POWER, Section D (1971) (1970 after-tax income); U.S. BuREau OF THE CENSUS, City GOVERnMENT FinanCes 1974-75, Table 5 (1976) (intergovernmental revenues, own-source revenues and total general revenues-fiscal 1975); U.S. Bureau of THE CeNSUS, CrTY GOVERNMENT FINANCES 1969-70, Table 5 (1971) (intergovernmental revenues, own-source revenues and total general revenues-fiscal 1970). 
More importantly, a comparison of columns 3 and 4 shows that this rapid expansion of outside aid has held down the revenue burden placed on citizens of larger cities to an average imcrease of less than onehalf of one percent of after-tax personal income, although here again there is substantial variation from city to city. Nineteen of these twentynine big cities were able to keep the tax burden on their citizens virtually unchanged ${ }^{106}$ by heavier reliance on the outside aid. ${ }^{107}$ Among these were four cities that increased the proportion of outside revenues substantially ${ }^{108}$ in order to keep tax burdens from increasing, and one city, Memphis, which was actually able to reduce local tax burdens substantially with only a modest mcrease in reliance on outside aid. Memphis was able to do this only through sizeable annexations, an alternative which was not available to the other larger cities.

At the other end of the spectrum are the cities that have increased the revenue burden on their citizens. The two cities that imposed the most substantial increases in burdens on their populations between 1970 and 1975-New York City and Cincinnati-did not greatly increase their reliance on outside aid. ${ }^{109}$ These cities relied heavily on outside aid to start with, so any substantial expansion would have been difficult. Two other cities-Denver and Seattle-let their local revenue burdens increase while the rate of growth in outside aid fell behind the rate of their own revenue growth. Only one other city, San Francisco, has also had a recent rate of increase in own-source revenues that exceeds the rate of increase in outside aid. Even so, the increase in personal income in San Francisco actually reduced the relative revenue burden on its citizens.

The substantial increase in reliance on outside sources of revenue in the last decade has kept tax burdens imposed by the nation's largest cities fairly constant relative to their citizens' ability to pay. However, this is a trend that cannot continue indefinitely. In 1975, there were already five of these large cities which got more than half of their general reveurues froin outside sources.

There are indications that some cities have already reached the limit of their capacity to obtain outside aid to cover expenditure growth.

106. Relative, that is, to after-tax personal income.

107. Those nineteen cities which kept the change in tax burden to less than 0.5 percent of after-tax personal income also increased outside aid at 6.8 times the rate they increased own-source revenues. See column 3 of Table 3.

108. Cleveland, Pittsburgh, San Antonio and St. Louis increased their outside revenues at an average of about $15 \frac{1}{2}$ times the rate at which they increased their own-source revenues.

109. See columns 3 and 4 of Table 3. 
New York City and Buffalo, for example, had three characteristics in common over the period 1970 to 1975 . First, they began the period with an already heavy reliance on outside aid. Second, they were able to expand that dependence on outside aid at less than one-half the rate aclieved by the other big cities over this period. Third, they greatly increased the fiscal burden on their own citizens. These factors indicate that both Buffalo and New York City have largely reached the limits on expansion of outside revenue sources and that the burden of increased expenditures has begun to be borne by their taxpayers.

Many of the other large cities face the same prospect in the immediate future. They can expect to find less rapidly expanding outside aid and will be forced to balance budgets with a combination of expenditure controls and additional revenues froin their own resources. The remaining discussion in this section describes soine of the difficulties the cities will encounter in expanding their revenue sources.

\section{A. The Property Tax}

In large part, the pattern of rising expenditures has placed increased pressure on the property tax. Cities of all sizes rely on the property tax for about 42 percent of the general revenues they collect from their own sources. ${ }^{110}$ In the past, this heavy reliance on the property tax has been founded on two inain rationales. First, there has been the notion that the property tax contributes to an equitable financing of local government by putting the tax burden on those who benefit inost froin municipal services ${ }^{111}$ and by enhancing local control over tax structure and rates. ${ }^{112}$ All those who own or rent ${ }^{113}$ homes or places of business in a city benefit from the police and fire protection, street maintenance and sewage systems which nost cities provide. All of those who live in a city (as homeowners or as renters) are able to vote

110. U.S. Bureau of the Census, CtTy Government Finances in 1974-75, Table 1 (1976).

111. See, e.g., L. Moak \& A. Hillhouse, Concepts and Practices in Local GovERNMENT FinANCE 126, 130 (1975); Harriss, Property Taxation: What's Good and What's Bad About It, 33 AM. J. EcoN. \& Soc. 89, 90-91 (1974).

112. H. Aaron, Who Pays the Property Tax? A New View 55 (1975); see R. MUSGRAVE \& P. MUSGRAVE, supra note 91, at 349.

113. Although renters are not usually taxed directly, real property taxes have been generally assumed to be shifted forward by landlords to their tenants. E.g., Kramer v. Union Free School Dist. No. 15, 395 U.S. 621, 630-31, (1969). The extent to which this occurs will depend on general market conditions in a particular area. H. AARoN, supra note 112, at 32-38, 42-43; see R. MUSGRAVE \& P. MUSGRAVE, supra note 91 , at 43536. 
on property tax rates ${ }^{114}$ and can thereby control both tax rates and local service levels.

Second, the property tax has historically provided a relatively stable taxable resource for local governinent. Once a particular area is incorporated into a municipality's boundaries, it is extremely difficult to remove that land froin the city's tax base. ${ }^{115}$ While a slight tax increase will normally lead to a decline in the quantity of the thing being taxed, the quantity of land in a city can rarely be increased or reduced..$^{116}$

The relative invulnerability of land values to fluctuations in the econoiny also contributes to the consistency of taxes on land as a source of revenue. While sales receipts and income may decline drastically, assessed land values generally remain fairly constant in a recessionary period. ${ }^{117}$ A further attraction of a property tax is that it may actually promote higher property values as owners of dormant or low-productivity property are forced to develop their properties in order to insure that

114. It is well settled that property ownership may not be established as a prerequisite to voting eligibility in tax referenda, see, e.g., Kramer v. Union Free School Dist. No. 15, 395 U.S. 621 (1969) (school district property tax), unless the tax is levied by a special purpose district the function of which is so far removed from normal governmental activities and the effect of which is so disproportionate that one man-one vote would be inappropriate. See Salyer Land Co. v. Tulare Lake Basin Water Storage Dist., 410 U.S. 719, 726-30 (1973). See generally City of Phoenix v. Kolodziejski, 399 U.S. 204 (1970) (property ownership cannot be a prerequisite to franchise in referendum on general election bonds); Cipriano v. City of Houma, 395 U.S. 701 (1969) (same for revenue bonds).

115. While the laws of many states provide procedures for area secession, see, e.g., 2 E. McQuillin, THE LAW OF MUNicipal Corporations $\$ \S 7.24-.25$ (3d ed., rev. vol., 1966), this process is both difficult and uncommon.

116. See H. AARoN, supra note 112, at 20-22, 40; Harriss, supra note 111, at 98. Landfills and annexation, plans for both of which may be sensitive to property tax rates, are the major exceptions. H. AARON, supra note 112, at 40 . Where land surrounding a city is not yet urbanized and is subject to a lower tax rate than land in the city, more rapid urbanization of the outlying area may result. See id. at 40-41. As long as state law permits annexation, the city can then increase its property tax base by incorporating this newly developed land into its boundaries. But see notes 3-21 supra and 144-51 infra and accompanying text.

The notion that land is in fixed supply is the primary reason for economists' traditional advocacy of land taxes. H. AARON, supra note 112, at 40 , citing D. NETZER, ECONOMICS OF THE ProperTy TAX 197-212 (1966), and sources cited therein.

117. As a practical matter, the consistency of the property tax base, particularly over short-term recessions, is the result of the relatively low speed of the property assessment process. Even if the value of land or a structure declines, this will not affect its owners' tax bill until the property is reassessed. Unless the change is so sudden that a special assessment can be obtained, this process can take several years, by which time the economy may have already begun to improve and the property may have returned to its original value. 
the land yields a return substantial enough to pay the taxes assessed and still provide a profit. ${ }^{118}$

Unfortunately, the traditional view about the stability of the property tax base overlooks important long-term consequences of such taxes. The property tax is not one tax but two: it is a tax on land, and it is a tax on structures built on the land. While the supply of land in a city is relatively fixed, the supply of capital available to develop or to maintain property in that city is variable; it depends on the relationship between the rate of return from capital investment there and the rate of return elsewhere. ${ }^{110}$ Thus, since the owner of land in a high tax jurisdiction will have to bear the burden of any increase im his property taxes caused by a rise in the value of his land, he will cease to put money imto the development of that property unless he can obtain as high a return from that use of his capital as he can from other imvestments. Imposition of a propery tax increase may thus precipitate a departure of capital from the jurisdiction, and that departure will continue until the rate of return on property investment in that jurisdiction once again equals the rate of return for capital in the rest of the capital market. ${ }^{120}$

This departure of capital has important consequences for the housing and labor markets in a high tax jurisdiction. First, the cost of housing in the high tax jurisdiction is likely to increase. ${ }^{121}$ As capital departs the jurisdiction, both the quantity and quality of housing will decline. Old assets will be allowed to deteriorate, and new construction will be rare. As the housing supply deteriorates, the cost of housing will, of course, go up as people are increasingly willing to pay more for less. A second effect of the departure of capital will be a decline in the wages of laborers who remain in the high tax jurisdiction. ${ }^{22}$ The

118. See L. MoAK \& A. Hillhouse, supra note 111 , at 130 . The landowner may also decide to sell his property to someone who can afford to make the appropriate investment.

119. See H. Aaron, supra note 112 , at $38-40$; R. Musgrave \& P. Musgrave, supra note 91, at 430-37. The discussion which follows is drawn from both of these works.

120. In this respect the real property tax functions much like a corporate income tax. For a particularly useful explanation of the equalization of net returns which results from an increase in these kinds of taxes, see R. Musgrave \& P. MUSGRAVE, supra note 91, at 416-18.

121. See id. at 432-33. In some financially strained cities, the mere threat of a potential tax increase may be a potent deterrent to improvements of central city residential properties. D. Netzer, IMPACT of the ProperTy TAX: EFFECT on Housing, Urban Land Use, Local Government Finance, 21-22 (Comm. Print 1968) (prepared for Joint Economic Comm. of Congress, 90th Cong., 2d Sess.).

122. See H. AARON, supra note 112, at 41-44; R. MusGrave \& P. Musgrave, supra note 91 , at 433; cf. id. at 418-19 (analogous effects of corporate income tax increases on wages). 
decrease in capital investment will be accompanied by a decline in the demand for labor. ${ }^{123}$ As demand for labor falls, lower salaries will necessarily result. ${ }^{124}$

Escalating taxes have combined with other factors such as the recent recession, racial motivations and a preference for lower population density to produce a substantial shift in population and employment opportunities away from America's aging central cities. This decrease in business and population has contributed to an erosion of the property tax base in many central cities. As central city residents and businesses depart for the suburbs or for other regions of the country, the demand for land in the central city can only decrease. ${ }^{125}$ This decrease in demand is necessarily followed by a decline in the value of land and housing and thus by an erosion of the city's tax base. ${ }^{126}$

Whether net emigration is the result of excessive tax burdens or other factors, it has clearly contributed to an erosion of the tax base in the central cities. Moreover, as the tax base shrinks, the tax rate must be increased to maintain current expenditure levels. This in turn intensifies the pressure for residents to leave their homes in stable inner city communities where property values have remained relatively con-

123. Tax rates clearly play an important role in the location decisions of major industries. In a recent speech before the National Tax Association, the senior vice president of E.I. duPont de Nemours Company explained that local tax and debt levels accounted for 45 of the 100 points which duPont allots in choosing locations for its new plants. Heckert, Metropolitan Fiscal Disparities-The Business Point of View, 29 NaT'L TAX J. 336, 337 (1976). One would expect that duPont's criteria are similar to those used by other major industries. See id.

124. In some areas which are highly dependent on industries in which labor and capital can be easily substituted for one another, the downward pressure on wages may be mitigated. See H. AARON, supra note 112, at 42-43; cf. R. MUSGRAVE \& P. MusGrave, supra note 91 , at 418 n.4.

125. According to Aaron, "Differences in tax rates within metropolitan areas are likely to be reflected primarily in land values." H. AARON, supra note 112, at 44 . If market response can be taken as an indicator, it is clear that the demand for suburban housing is presently much stronger than that for housing in the central cities. "Of new housing constructed between 1970 and 1974,45 percent was located in suburban areas, while 21 percent [only half as much] was located in central cities." 1976 REPORT ON NATIONAL GRowTH AND DEVELOPMENT 39. A similar market shift seems apparent in data for the commercial sector. During the 1970 s, suburban employment has grown much more rapidly than employment in the central cities. This has been particularly true in manufacturing where larger investments in land are necessary. Id. at 31-33; IMPROVING URBAN AMERICA 218.

126. See Peterson 54-55. The decline in property values may be particularly acute in cities which are parts of declining metropolitan areas. In such areas, there may be an excess of housing for the entire area so that property values throughout the metropolitan housing market begin to decline. Unlike cities in growing metropolitan areas where sustained suburban growth will help to maintain city housing prices to some extent, the city in a declining metropolitan area may find hittle demand for its housing. 
stant, and it increases the incentive for businesses to migrate to coininunities with inore advantageous tax structures.

The situation is aggravated by the highly fraginented tax systems which are faced by the taxpayers of most American cities. In order to avoid the debt and tax limitations which virtually every state has imposed on its local governments, ${ }^{127}$ most communities have established a variety of special districts and authorities which have powers to tax and borrow even though the general purpose government which they overlap has already met its taxing linitation. ${ }^{128}$ In 1972 , there were over 8,000 special districts in America's 264 SMSAs. ${ }^{128}$ While such units nay be highly effective when they are carefully planned, they can be quite dysfunctional when established primarily for the purpose of escaping tax and debt restrictions. Such fragmentation may create diseconomies of scale and unnecessary duplication of services. More inportantly, a proliferation of special purpose districts nnay render traditional tax limits useless and subject residents to multiple tax burdens which increase pressure to leave the central city for less service-intensive locales. ${ }^{130}$ In a

127. For a thorough overview of state constitutional and statutory limitations on local government taxation as of 1971, see U.S. ADVISORY COMMISSION ON INTERGOVERNmental Relations, State-Local Revenue Systems and Educational Finance, Appendix C (rev, ed. 1971). The problems with these restrictions are detailed in U.S. advisory Commission on Intergovernmental Relations, State Constitutional and Statutory Restrictions on Local Government Debt (1961) and U.S. ADVisory Commission on Intergovernmental Relations, State ConstTtutional and Statutory Restrictions on Local TAXING Powers (1962). The madequacies that were present in the early 1960 s are still present today. See, e.g., L. MOAR \& A. HiLLHOUSE, supra note 111, at 274-78; U.S. ADVISORY COMMISSION ON INTERGOVERNMENTAL Relations, State-Local Revenue Systems and Educational Finance, supra, Appendix $C$ at $C-1$. The results of one recent study suggest that these limitations have not been effective in keeping a lid on property taxes. See Shannon, Bell \& Fisher, Recent State Experience with Local Tax and Expenditure Controls, 29 NAT'L TAX J. 276 (1976). Another analyst has suggested that such limitations may have an unintended dysfunctonal impact on services in regions that need them most. See Pogue, The Effect of Debt Limits: Some New Evidence, 23 NaT'L TaX J. 36 (1970).

128. Compare IMPROVIng URBan AMERICA 147 with U.S. AdVISORY COMMISSION ON INTERgovernmental Relations, State CoNstitutional and StatutoRy Restrictions ON LOCAL GOVERNMENT DEBT 58 (1961).

129. U.S. Bureau of the Census, 1972 Census of Governments, Local Governments in Metropolitan Areas 10, 18 (Table 2) (vol. 5 1975). "SMSA" is an acronym for the Standard Metropolitan Statistical Area(s) within which the Census Bureau measures the population of major urban centers.

130. The relevant inquiry in insuring fiscal stability is not how much a particular unit of government can properly borrow or tax but how much a particular tax base can support. See, e.g., U.S. AdVISORY CoMmission on INTERgovernMENTAL ReLations, State Constitutional and Statutory Restrictions on Local Government Debt 3942 (1961); U.S. ADVISORY COMmission ON INTERgoVernmental RELATIONS, State Constitutional and Statutory Restrictions on local Taxing Powers 9 (1962). It makes little difference whether one unit takes 20 'percent of its citizens' income or four 
city like Chicago, for example, where a property owner is taxed not only by the city but by a county, a park district, a school district, a forest preserve, a sanitary district and a myriad of other special purpose districts, ${ }^{131}$ any decrease $\mathrm{m}$ the tax base effected by emigration will force an increase in the tax rate imposed by each of these overlapping units of government. In addition, a pattern of consistently higher property taxes in the central cities may undermine one of the most attractive features of this tax, namely its relatively progressive nature. ${ }^{132}$

\section{B. Maintaining the Tax Base}

To the extent that urban emigration has mvolved noves to the suburbs rather than to other regions of the country, the cities have traditionally been able to recapture their tax bases through annexation and consolidation. ${ }^{133}$ This capacity to grow and recapture emigrants is critical to a central city's ability to nuaintam its fiscal integrity. As a city grows, it develops facilities which produce benefits not limited to its own citizens. ${ }^{134}$ Commercial and entertainment centers, sports facilities, mass transit systenis and facilities for the furtherance of the arts and sciences all develop to their fullest in the mature urban center. Suburbanites return to the city each day to work, shop, and conduct business, and again at night and on the weekends for entertainment and recreation. The city is the center of a complex market; and just as a merchant must be careful to prevent his customers from leaving his premises without paying for his wares, the city must develop methods of forcing its customers-those who labor, visit or pass their leisure there- to pay for the services provided within its boundaries.

In some cases, it will be very easy for the city to charge suburbanites directly for urban amenities through the imposition of "user charges." Where the benefits of a particular urban service can be

units take 5 percent each from the same citizens; the burden is the same. Although it is clearly aggregate burden that is the appropriate focus, no state appears to have adopted that approach. See Shannon, Bell \& Fisher, supra note 127, at 281-83.

131. See IMProving URBAN AMERICA 146-50.

132. See H. AARON, supra note 112, at 54-55. According to Aaron, the modern view holds that when property taxes are increasing steadily, the burden of the increases is borne by the owners of capital and this results in the tax being relatively progressive. If rates in a locality are not part of a general nationwide pattern of tax increases, however, then the traditional view holds that much of the burden of the local tax increases can be shifted to consumers and the tax loses its progressive nature.

133. For a discussion of annexation procedures and the inability of the older cities to annex new territory, see notes 144-51 infra and accompanying text.

134. This creates what an economist would term an externality. See generally R. MUSGRAVE \& P. MUSGRAvE, supra note 91 , at $49-80$ (theory of social goods). 
limited to a particular group of people, those people can be charged directly for the service. Museum and swimming pool admission fees, public parking meters and road tolls are all examples of charges for these kinds of focused services. ${ }^{135}$ In general, such service charges have been applauded by economists because of their equitable allocation of costs among all actual recipients of benefits. ${ }^{136}$

Unfortunately, it appears unlikely that user charges can play a major role in the fiscal rejuvenation of the central cities. To begin with, in many jurisdictions there are important legal impediments to their imposition. ${ }^{137}$ In many states, user charges cannot be imposed because of a lack of specific authorization or an explicit prohibition. Moreover, licenses and fees are generally limited to the amounts required to cover the costs of the particular service or regulatory scheme on which the fee is imposed. ${ }^{138}$ These requirements keep fees to a minimum and restrict the ability of the cities to utilize user charges as a mechanism for recapturing the wealth of its suburban visitors. Given these difficulties, it is not surprising that the cities' reliance on user charges as a source of revenue has increased only slightly in recent years. While almost 13 percent of the revenues raised by cities came from "current charges" in $1957,{ }^{130}$ such charges provided barely 18 percent of the local revenues raised from the cities' own resources in fiscal 1975..$^{140}$

Ultimately, user charges are simply inappropriate means for financing most urban functions. The benefits of most city services are not

135. For an interesting discussion of the factors to be considered in imposing charges for sewer service, water service, parking meters and road use, see LOCAL REvENUE DIVERSIFICATION 68-76.

136. E.g., id. at 64. It should be noted, however, that such fees may be vulnerable to severe criticisms from the standpoint of equity. A user fee for museum or park admission would have a substantially more adverse effect on the ghetto resident than on his suburban neighbor. School lunch and hospital fee charges are subject to similar criticisms.

137. Id. at 67. See generally 2 E. MCQuilin, supra note $115, \S 26$.

138. LoCal Revenue Diversification 67; 9 E. MCQuillin, supra note 115 , $\$ 26.15$, at 31. See, e.g., Concrete Contractors' Ass'n v. Village of LaGrange Park, 14 Ill. 2d 65, 150 N.E.2d 783 (1958) (implies from village's power to regulate the power to exact a license fee in order to defray costs of regulation).

139. Local Revenue Diversification 7, 12. The United States Bureau of the Census defines "current charges" as

amounts received from the public for performance of specific services benefiting the person charged and from sales of commodities and services other than city utilities .... Current charges are distinguished from license taxes, which relate to privileges granted by the government or regulatory measures for the protection of the public. U.S. BUREAU OF THE CENSUS, CITY GOVERNMENT FINANCES IN 1964-65, at 75 (1965).

140. See U.S. Bureau of the Census, Crty Government Finances In 1974-75, at 5 (Table 1)(1976). 
easily inatched with specific categories of individuals. Anyone who visits a city receives the benefits of its police, fire and sanitation departments. Even the benefits of education are not realistically confined to the students who attend a particular scliool system. An entire community may benefit from having its children well educated. Higher education levels will increase community wealth and benefit all citizens living therein. Open space and pollution control have similarly broad effects.

As long as a city's boundaries encoinpass the entire population that benefits froin its services, the inability to inpose user charges for certain core municipal functions does not present a problem. Where the population that consumes a city's services resides within the city linits, that population will be subject to the city's property tax and may vote to control the relationship between the services they want to receive and the taxes they are willing to pay. ${ }^{141}$ A problem develops, lowever, when an urban area grows beyond the boundaries of its central city and the city can no longer expand to encoinpass its natural market area. ${ }^{\mathbf{1 4 2}}$ When this happens, a city can be thrust into a position of severe financial strain. The central city must inaintain police and fire protection and street and sanitation systems which can accommodate the inillions of people who visit each day but return each night to homes beyond its traditional tax jurisdiction. A city of 500,000, for exainple, might liave to inaintain services sufficient to accominodate over 1 million blue- and white-collar laborers who coinnute to and from its boundaries every day. ${ }^{143}$

Historically, the cities have been able to grow with their nuarket areas through annexation and/or consolidation. ${ }^{144}$ For a variety of reasons, both legal and practical, it now appears that this option is

141. See notes 111-14 supra and accompanying text.

142. An excellent discussion of the importance of reuniting the cities with their market areas can be found in Peterson 72-84.

143. There is, of course, some "reverse commuting" where people travel away from the central cities in the morning and toward them at night. See generally D. NETZER, Economics and Urban Problems: Diagnoses aNd Prescriptions 78.80 (1970); Babcock \& Weaver, Exclusionary Suburban Zoning: One More Black Rebuff to the Latest Liberal Crusade, in THE URBAN SCENe IN THE Seventies 208-09 (J. Blumstein \& E. Martin eds. 1974). Unfortunately, this merely exacerbates the problem. The lowincome worker with his minimal tax contribution leaves the city to contribute to a business whose income and property cannot be taxed by his home city.

144. Annexation involves the expansion of inunicipal boundaries. Although procedures may differ according to state law, both incorporated and unincorporated territories may be annexed by most large cities. Consolidation, on the other hand, involves the merger of one local government with another so that an entirely new entity is created. See F. Sengstock, Annexation: A Solution to the Metropolitan Area Problem 7, 42-44 (1960). 
completely foreclosed for the aging central cities which are currently experiencing population losses. ${ }^{145}$ Given the relationships between growth and fiscal strength which have already been described, it seems extremely unlikely that the cities would not annex if they had the power to do so. In most cases, however, the state statutes that prescribe annexation procedures ${ }^{\mathbf{1 4 6}}$ make it extremely difficult for older central cities to expand through annexation. Unlike some of the newer growing cities of the South and West, most of the older urban centers of the industrial Northeast are surrounded by a belt of smaller suburban communities which are also imcorporated. In order to protect themselves from absorption by their larger neighbors, the residents of urban fringe areas have lobbied effectively in many states for statutes which require concurrent majorities of the voters in both the annexing city and the area to be annexed in order for one imcorporated community to annex the territory of another. ${ }^{147}$ In some states, a mumicipal corporation cannot annex territory in another incorporated region under any circumstances. ${ }^{148}$ Similar problems may arise for cities in states where inhabitants of unincorporated areas may exercise a unilateral veto over an attempted annexation by a neighboring city. ${ }^{149}$

Clearly, such statutes present a substantial impediment to the cities' abilities to inamtain legal jurisdiction over their market areas. Defen-

145. See notes 3-21 supra and accompanying text.

146. As a creature of the state, a municipal corporation's power to extend its boundaries is completely a matter of state law. See 2 E. McQuilLIN, supra note 115, $\$ 7.10$, at 309 . For a particularly strong statement of the states' power over municipal boundary changes, see Hunter v. City of Pittsburgh, 207 U.S. 161, 178-79 (1907), discussed in note 161 infra. The effects of Hunter are discussed in Note, The Right to Vote in Municipal Elections, 88 HARv. L. Rev. 1571, 1571-73 (1975).

147. E.g., VA. CODE $\$ \S 15.1-1032$ to -1058 (Supp. 1976); Wash. Rev. CoDE $\S$ 35.12010 (1976); see Alternative Approaches to GoVERnMENTAL REORGANization IN METROPOLITAN AREAS 59 (1962). In solne states, concurrent majorities are required regardless of whether the area to be aunexed is incorporated or not. E.g., ILL. ANN. Stat, ch. 24, § 7-1-7 (Smith-Hurd Supp. 1976); Tex. Rev. Civ. Stat. AnN. art., 1182a (Vernon 1963) (home rule cities only). It should be emphasized that such schemes are not presently constitutionally required. Cf. Note, supra note 146, at 1573-87 (arguing that a constitutional right for residents of annexation target areas to vote on annexation proposals should be established).

For general discussions of the present state of the law with respect to annexation of incorporated areas, see C. ANTIEAU, 1 MUNICIPAL CORPORATION LAW $\S 1 \mathrm{~A}$, at 19 (1975); 2 E. MCQUILLAN, supra note $115, \S 7.22$; F. SENGSTOCx, supra note 144 , at $42-$ 44.

148. E.g., TeX. Rev. Civ. Stat. ANN. art. 970(7) (Vernon 1963) (does not apply to home rule cities). Similar results have been reached by judicial decision in states whose annexation statutes only provide explicitly for annexation of incorporated territory. See 2. E. MCQuILIIN, supra note $115, \$ 7.22$, at $374-75$ and cases cited therein.

149. E.g., 2 E. MCQumIIN, supra note 115 , $\$ 7.37$, at 469-70. 
sive incorporation nray lead to a proliferation of small municipalities, which fragments the market area and makes both coordinated economic developnient and efficient dehvery of urban services impossible. ${ }^{150}$ The general lack of statutory guidelines for review of incorporations ${ }^{151}$ aggravates the problen by allowing small enclaves of residential communities or manufacturing facilities to incorporate themselves in order to avoid being encompassed by the high tax jurisdiction of the neighboring city on which they often depend for their existence.

Even when a state statute allows unilateral annexation of fringe territories, the existence of these small unidimensional enclaves can make rational urban development virtually impossible. Though it would be theoretically pleasing for the central city to impose its taxes on the members of the suburban communities who use its facilities each day, it may be fiscally impractical for a central city to annex many of the residential communities at its fringe, since the simgle family dwellimg may inipose a serious burden on the public fisc. Coinpared to an apartment complex or factory, the taxable value of property used for single family dwellings can be extremely low. Yet the burdens imposed by such property in terms of water service, road maintenance, and police and fire protection are substantial because of the spatial dispersion of single family neighborhoods. At the other extreme, high-density lowcost housing may present comparable burdens as costs connected with high population densities escalate due to problems associated with traffic, police protection, and refuse control, and as assessed values fall because of economies of scale in apartment housing. In niany cases the city simply cannot afford to annex either type of community.

The situation becomes even more onerous when the fringe coinmunities adopt exclusionary zoning ordinances. By restricting an area to single-family dwellings ${ }^{152}$ or one-acre lots, ${ }^{153}$ or by passing an ordinance forbidding the use of nobile homes ${ }^{154}$ in a particular area, fringe communities often contribute to an inefficient concentration of poor in the central cities.

150. E.g., Note, An Act to Establish Standards and Procedures for Municipal Boundary Adjustment, 2 HaRv. J. Legrs. 239, 242 (1965).

151. See Mandelker, Municipal Incorporation and Annexation: Recent Legislative Trends, 21 OHо ST. L.J. 285 (1960).

152. See, for example, the ordinance which the Supreme Court held constitutional in Village of Belle Terre v. Boraas, 416 U.S. 1 (1974).

153. Such an ordinance was struck down as a matter of state law in Oakwood at Madison, Inc. v. Township of Madison, 45 U.S.L.W. 2379-80 (N.J., Jan. 29, 1977), aff'g 117 N.J. Super. 11, 283 A.2d 353 (Law Div. 1971).

154. Such an ordinance was upheld by the New Jersey Supreme Court in Vickers v. Township Comm., 37 N.J. 232, 181 A.2d 129 (1962), cert. denied, 371 U.S. 233 (1963). 
As a practical matter, people will locate so as to maximize their accessibility to other people and activities with whom they need to or want to have frequent contact. ${ }^{155}$ In recent years there has been a substantial change in the spatial distribution of urban employment. ${ }^{156}$ The development of the shopping center has led increasing numbers of retailers to leave the cities for the cheaper property and large concentrations of consumers in the suburbs. ${ }^{157}$ More importantly, there has been a departure of manufacturing plants from the central cities of the industrial Northeast. ${ }^{158}$ At the same time, there has been a major increase in the number of white collar jobs-in banking, fimance, the law, and government-that are available in the central cities. ${ }^{159}$

155. See D. Netzer, Economics and Urban Problems: Diagnosis and PrescripTIONS 10 (2d ed. 1974); Burchell, Listokin \& James, Exclusionary Zoning: Pitfalls of the Regional Remedy, 7 URBAN LAw. 262, $271-73$ (1975) (presents findings of some statistical research on this point). Netzer presents an interesting analysis of economic factors which shape the location decisions of urban residents. D. NETZER, supra at 9-18. For other discussions of factors which shape the spatial structures of urban areas, see Internal Structure of the City: Readings on Space and Environment (L. Bourne ed. 1971).

156. See P. Porter, The Recovery of American Cities 51-62 (1976).

157. Between 1963 and 1972, retail sales in the suburbs increased by almost 230 percent. During this same period, the increase in retail sales in the central cities was less than 160 percent. Little of the growth in retail sales that did occur in central cities occurred in the central business district. See Improving Urban America 218 (Tables XXX and XXXI) (1976).

158. See P. Porter, supra note 156, at 51-56; 1976 RePort on NATional Growth AND DEVELopMENT 31-32 (in many of the declining central cities, manufacturing employment has actually declined, Table II-8); Improving URBAN AMERICA 218 (Table XXXII) (1976).

Currently, there is a serious debate concerning the extent to which this loss in manufacturing employment is due to emigration to the suburbs or to other areas of the country. On one hand, it has been suggested that lower tax rates, the presence of large labor supplies, and the availability of cheaper open space in the South and Southeast have attracted increasing numbers of major businesses away from the central cities of the industrial Northeast. E.g., JEC PRINT 13; T. MULIER, supra note 25, at 6-8; P. PORTER, supra, at 55. Also see notes 224-27 infra and accompanying text. However, the most recent evidence indicates that actual "migration" of firnis has played only a minor role in the changing employment situations of the northern industrial tier and the sunbelt. See note 227 infra.

159. See P. Porter, supra note 156, at 54. According to Paul Porter, New York is illustrative of the trend: between 1960 and 1970, when New York's population rose by 1.5 percent, the number of manufacturing jobs fell from 947,000 to 773,000 -down 18 percent in a time of rising prosperity. Id. But these losses were more than offset. Jobs in the financial sector increased by 90,000 and the city job sector showed a job increase of about 145,000. Id. at 51,54. This increase in local public sector jobs is characteristic of central cities throughout the country. Peterson 112; see JEC PRINT 23. See also Jusenius \& Ledebur, $A$ Myth in the Making: The Southern Economic Challenge and the Northern Economic Decline 41 (prepublication copy prepared for Economic Development Administration, U.S. Dep't of Commerce 1976)(suggesting that the growth project- 
While one would expect some population shifts to occur, thereby bringing laborers closer to their respective places of work, exclusionary zonimg schemes make this movement impossible. Frequently, the industrial laborer who lives in Detroit or Cleveland cannot afford to move to follow his job. Where he can afford to move, he may be precluded from finding housing within his price range because of zoning restrictions on lot sizes, multiple-family dwellings or trailer parks.

The inability of the blue collar worker to leave the city to live closer to his job also limits the inclimation of the white collar worker to move back into the central city to live closer to his. Until the poor can fimd a way out of the inner city, city dollars will have to be devoted to urban renewal and low-income housmg rather than to those amenities which might be attractive to the white collar worker. ${ }^{160}$

In recent years, a number of state courts and legislatures have begun to recognize the serious problems that can be caused by restrictive annexation and zoning schemes and have begun to fashion solutions through judicial and legislative decisions. ${ }^{161}$ Most states now allow

ed in the next decade for the service, finance, insurance and real estate industries may be crucial to the continuing growth of employment opportunities in the industrial Northeast).

160. The financial burden on the cities is further aggravated by two other phenomena. First, the movement of a manufacturer may cause additional unemployment (with all the costs which that entails) in the central cities if inner city residents who cannot afford to move cannot afford to commute either. See 1976 REPORT FOR NATIONAL Growth AND DEvelopment 33. Second, the inability of the poor to move the city boundaries outward may contribute to an increase in the city's population density, and the costs of many urban services are thought to increase with increased density. See A. OtT \& J. Yoo, New York City's Financial Crisis: Can the Trend Be Reversed? 2728 (1975).

161. It is important to emphasize the inability of the federal judiciary to deal with these problems. As the Supreme Court explained at the turn of the century in Hunter v. City of Pittsburgh, 207 U.S. 161, 178-79 (1907):

Municipal corporations are political subdivisions of the State, created as convenient agencies for exercising such of the governmental powers of the State as may be entrusted to them. ... The number, nature and duration of the powers conferred upon these corporations and the territory over which they shall be exercised rests in the absolnte discretion of the State .... The State . . . at its pleasure may modify or withdraw all such powers, ... [or] expand or contract the territorial area, unite the whole or a part of it with another municipality, repeal the charter and destroy the corporation. All this may be done, conditionally or unconditionally, with or without the consent of the citizens, or even against their protest. In all these respects the State is supreme, and its legislative body, conforming its action to the state constitution, may do as it will, unrestrained by any provision of the Constitution of the United States.

Hunter involved a challenge to a Pennsylvania statute which provided for the union of contiguons municipalities. See $i d$. at 161-64. The case has frequently been cited for the proposition that states may set up any annexation procedure they wish without according any voice to citizens of the area targeted for annexation and without fear of federal intervention. See Murphy v. Kansas City, Mo., 347 F. Supp. 837 (W.D. Mo. 
1972) (annexation election open only to voters in annexing area); Detroit Edison Co. v. East China Twsp. School Dist., 247 F. Supp. 296 (E.D. Mich. 1965), aff'd, 378 F.2d 225 (6th Cir.), cert. denied, 389 U.S. 932 (1967) (annexing school district acted only by vote of board of election, while residents of the annexed area approved by referendum); Note, supra note 146, at 1571-72 \& n.9, citing Deane Hill Country Club, Inc. v. City of Knoxville, 379 F.2d 321 (6th Cir.), cert. denied, 389 U.S. 975 (1967) (annexation by action of annexer's governing board); cf. People ex rel. Landwer v. Village of $\mathrm{N}$. Barrington, 94 Ill. App. 2d 265, 237 N.E.2d 350 (1968) (statute which requires notice of impending annexation to be published in a newspaper does not violate the fourteenth amendment by failing to require personal notice).

The Supreme Court has also been reluctant to reject local zoning ordinances on any but the most flagrant grounds. The standard of review for zoning cases was set forth fifty years ago in Village of Euclid v. Ambler Realty Co., 272 U.S. 365 (1926), in which the Court was faced with a claim that a zoning ordinance which prohibited a landowner who had been holding vacant land for industrial development from doing so was an unconstitutional taking of liberty and property without due process. The Court rejected this claim, holding that the zoning ordinance was a reasonable exercise of the states' police powers. See id. at 386-88. According to the Court, the legislative judgment that a particular zoning classification was necessary to protect the public welfare would have to be upheld as long as the judgment was "fairly debatable." Id. at 388. The general exclusion of all industrial establishments from residential districts was validated as a "reasonable margin to insure effective enforcement" of the ordinance. Id. See also Berman v. Parker, 348 U.S. 26 (1954) (upholding an urban improvement project against a challenge of taking without just compensation). According to the Court, the concept of public welfare is broad and covers values that are spiritual as well as physical, aesthetic as well as monetary. Id. at 33.

The Court has taken a similarly strong position against equal protection challenges to zoning ordinances. In the recent case of Village of Belle Terre v. Boraas, 416 U.S. 1 (1974), the Court upheld a local ordinance which restricted land use to single-family dwellings with the word "family" defined to mean one or more persons related by blood, adoption, or marriage or not more than two unrelated persons living together as a single household. Rejecting the argument of six unrelated college students who had rented an apartment, the Court held that the ordinance did not violate equal protection as long as it bore a rational relationship to a legitimate state objective (the Court pointed to the avoidance of traffic and congestion, id. at 5) and did not impinge on any fundamental right. Id. at 4-8.

More recently, in Warth v. Seldin, 422 U.S. 490 (1975), the Supreme Court placed what may be an insurmountable obstacle in the path of most constitutional attacks on exclusionary zoning provisions. In Warth, three plaintiffs-a non-profit corporation devoted to fostering housing for low-income groups in the Rochester area, several Rochester taxpayers, and several Rochester residents with low incomes who were also members of minority groups-sought to challenge a zoning ordinance of a suburb of Rochester on the ground that it excluded people of low and moderate income. The Supreme Court upheld a dismissal of the action on the ground that none of the plaintiffs had standing to challenge the ordinance. According to the Court, a plaintiff who seeks to challenge exclusionary zoning practices on constitutional grounds must allege that such practices harm him and that he would benefit personally and tangibly from the court's intervention. Id. at 508. Clearly neither the Rochester taxpayers nor the nonprofit corporation could meet this standard. Id. at 508-14. The Court refused to grant standing to the low-income plaintiffs because none of thein had shown that they would have been able to purchase suitable housing in the suburb at an affordable price in the absence of the zoning ordinance. Id at 502-07. There was no evidence that appropriate housing would have been built in the absence of the zoning ordinance-in other words, 
Inunicipalities to initiate annexation procedures by ordinance ${ }^{102}$ so that costly and time-consuming petition and election procedures can be avoided. Many of the states also prohibit unincorporated fringe areas from exercising a unilateral veto. ${ }^{163}$ Such prohibitions prevent residents of fringe communities from standing in the way of rational urban development merely in order to avoid inclusion in the tax base of any municipality. ${ }^{164}$

The most significant recent development in the area of boundary adjustments has been the increased use of local government boundary commissions. Since 1964, the United States Advisory Commission on Intergovernmental Relations (A.C.I.R.) has recommended that the state legislatures establish local government boundary commissions to:

(1) approve new municipal corporations;

(2) dissolve or consolidate non-functional local governments;

(3) limit the creation of new special districts;

(4) consolidate or dissolve special districts;

(5) oversee nunicipal annexations; and

that the plaintiffs' inability to locate in the suburb was not the consequence of the economics of the area housing market but of the zoning ordinance. Id. at 506 .

After Warth, it seems clear that a plaintiff will not be able to obtain standing to challenge a zoning ordinance on constitutional grounds unless he can show that a particular housing development which could meet his housing needs at a price he could afford was not built because of the challenged ordinance. It seems likely that this standard will be met only in the most flagrant situations where a city has either explicitly changed its zoning law to stifle a project which would have directly benefited a plaintiff, see United States v. City of Black Jack, 508 F.2d 1179 (8th Cir. 1974) cert. denied, 422 U.S. 1042, rehearing denied, 423 U.S. 884 (1975); Kennedy Park Homes Ass'n v. City of Lackawanna, 436 F.2d 108 (2d Cir. 1970), cert. denied, 401 U.S. 1010 (1971), or possibly, where a city had refused a variance for a proposed project, see Metropolitan Housing Dev. Corp. v. Village of Arlington Heights, 517 F.2d 409 (7th Cir. 1975), rev'd on other grounds, 97 S. Ct. 555 (1977), discussed in note 190 infra. (For a comprehensive treatment of Warth and other recent developments in the law of standing, see Comment, Constitutional Challenge to the Price-Anderson Act: Ripeness and Standing Before the Holocaust, 1976 DukE L.J. 967, 972-85.)

Given the fundamental importance of land use decisions as a state and local governmental function, it seems likely that the tenth amendment will impede any congressional use of the commerce clause to require regional zoning programs. Cf. National League of Cities v. Usery, 426 U.S. 833 (1976), discussed in notes 81-89 supra and accompanying text.

162. IMPRoving URBan AMERICA 167.

163. Id.

164. It should be noted, however, that most states will not permit a fringe area to be annexed merely to enhance the tax base of the annexing city. See Woodroof, Systems and Standards of Municipal Annexation Review: A Comparative Analysis, 58 Geo. L.J. 743,752 (1970). Many states also place special restrictions on the annexation of farmland, see id. at 750-51, to protect farmers from high property taxes that may make agricultural land uses financially infeasible. 
(6) develop spheres of mumicipal influence. ${ }^{165}$

Commissions with some or all of the powers suggested by the A.C.I.R. have been established in at least eight states. ${ }^{166}$ Statewide commissions are currently in operation in Alaska, ${ }^{167}$ Iowa, ${ }^{168}$ Michigan, ${ }^{160}$ Minnesota ${ }^{170}$ and New Mexico. ${ }^{171}$ California, Oregon and Washington have established boundary commissions at the local level. ${ }^{172}$ While the power of these commissions is generally limited by statutory standards or criteria included in their enabling legislation ${ }^{173}$ and by other statutory provisions which require voter approval of certain boundary adjustinents, ${ }^{174}$ these restrictions have not affected the major purposes of the A.C.I.R. recommendations. The statutory standards are quite broad and leave the cominissions with substantial discretion. ${ }^{175}$ While requirements of voter approval do prevent the commissions froin implementing central city expansions on their own motion, ${ }^{170}$ they do not inhibit their ability to impede defensive incorporations, annexations, or special purpose district consolidations, since commission approval inust generally be obtained for all such actions.

The primary advantage of these boundary commissions, particularly those at the state level, is that they help to depoliticize the boundary

165. Improving URban AMERICA 167-68. The A.C.I.R. has also recommended that these commissions concern themselves with county and other sub-state district boundaries. Id. For a useful legal analysis of the operation of such commissions, see Woodroof, supra note 164, at 745-46, 753-64.

166. Specifics of these commissions' powers and their relative strengths and weaknesses are discussed in IMPRoving URBAN AMERICA 168-70; Woodroof, supra note 164, at 753-64. Citations to specific statutory authorizations for the commissions are set forth in notes 167-72 infra.

167. Alaska STAT. $\S \S 44.19 .250, .260$ (1976), $\$ 29.68 .010$ (1972).

168. Iowa CODE ANN. $\$ 368.9$ et seq. (1976).

169. Мıсн. Сomp. L. ANN. $\S \S 123.1001$ et seq. (Supp. 1976).

170. Minn. Stat. ANN. $\$ \$ 414.01$ et seq. (Supp. 1977). Established in 1959, Minnesota's municipal commission was the first statewide boundary commission established in this country. A useful discussion of its operation can be found in Note, The Minnesota Municipal Commission-State-Wide Administrative Review of Municipal Aunexations and Incorporations, 50 MINN. L. REv. 911 (1966).

171. N.M. STAT. ANN. §§ 14-7-11 et seq. (1976).

172. See CAl. Gov't Code $\$ 54790$ et seq. (West Supp. 1976); Ore. Rev. Stat. $\S 199$ (Replacement Part 1975); WASH. Rev. CoDE $\$ \$ 36.93$ et seq. (Supp. 1976).

173. Woodroof, supra note 164, at 753-62; e.g., CAL. Gov'T CoDE $\$ 54796$ (West Supp. 1976); Мich. Comp. L. ANN. \$ 123.1009 (Supp. 1976); MinN. Stat. ANN. $\S 414.031$ (4) (Supp. 1977); WASH. REv. CODE $\$ 36.13 .173$ (Supp. 1976).

174. E.g., Mrch. Comp. L. ANN. \$ 123.1010 (Supp. 1976); Ore. Rev. Stat. § 199.480 (Replacement Part 1975); WASH. Rev. Code \$ 36.93.150(2) (Supp. 1976).

175. See Woodroof, supra note 164 , at 753-62. Specific examples may be found in the provisions cited in note 173 supra.

176. In some instances the commissions are authorized to initiate boundary changes or consolidations of special purpose districts on their own motion. E.g., ORE. REv. STAT. 
adjustment process by focusing attention on rational urban development rather than on the vested interests of the competing governmental units and their residents. Their utility is manifest from the experiences of the various states in which they are presently in operation. Where the commissions have the discretion to inodify incorporation and annexation proposals, ${ }^{17 \tau}$ new incorporations appear to have been slowed and central cities have been allowed to expand more rationally. ${ }^{178}$ Defensive incorporations have been dramatically reduced, and it appears that a number of proposals that were not in the interest of the region were either withdrawn or not even submitted when faced with the prospect of commission rejection. ${ }^{179}$ Where they have the authority, the commissions have also been successful in reducing the growth and actual numbers of special purpose districts within their jurisdictions. ${ }^{180}$

More recently, some of the state courts have begun to take action to insure that urban growth will not be impeded by exclusionary zoning in fringe communities. ${ }^{181}$ Most zonmg ordinances derive their force from the state's police power-the power to protect the public health, safety, morals or general welfare. ${ }^{182}$ To the extent that this is true, a zoning ordinance can be valid only if it yields a positive benefit to the state as a

$\$ 199.485$ (Replacement Part 1975). In Oregon, the local commissions may actually initiate and execute certain minor changes without any voter or governmental approval. Id. $\$ 199.487$.

177. E.g., Minn. Stat. Ann. $\$ 414.02(3)$ (Supp. 1977); ORE. Rev. Stat. § 199.461 (Replacement Part 1975).

New Mexico's commission is the noticeable exception in this regard. Under N.M. STAT. ANN. \$ 14-7-15 (1976), the state municipal boundary commission is authorized only to determine whether certaim statutory prerequisites have been met. When these conditions are met, the commission must order annexation. If the conditions are not satisfied, the petition must be denied. See Woodroof, supra note 164, at 762-63.

178. See IMPRoving URBan AMERICA 170. In Minnesota, for example, the "commission's first decade of experience showed a drastically reduced rate of new municipal corporations and a doubling of their average size." Id.

179. See id.

180. Id.

181. E.g., Bristow v. City of Woodhaven, 35 Mich. App. 205, 192 N.W.2d 322 (1971); Southern Burlington County NAACP v. Township of Mt. Laurel, 67 N.J. 151, 336 A.2d 713, cert. denied, 423 U.S. 808 (1975); Berenson v. Town of New Castle, 38 N.Y.2d 102, 341 N.E.2d 236, 378 N.Y.S.2d 672 (1975). See also Oakwood at Madison, Inc. v. Township of Madison, 117 N.J. Super. 11, 283 A.2d 353 (Law Div. 1971), aff'd, 45 U.S.L.W. 2379-80 (N.J., Jan. 29, 1977); Golden v. Planning Bd., 30 N.Y.2d 359, 285 N.E.2d 291, 334 N.Y.S.2d 138, appeal dismissed, 409 U.S. 1003 (1972); Appeal of Girsh, 437 Pa. 237, 263 A.2d 395 (1970).

182. See, e.g., Village of Euclid v. Ambler Realty Co., 272 U.S. 365, 395 (1926); Allen v. Coffel, 488 S.W.2d 671, 678 (Mo. Ct. App. 1972); Oakwood at Madison, Inc. v. Township of Madison, 117 N.J. Super. 11, 15-16, 283 A.2d 353, 355-56 (Law Div. 1971); Board of Supervisors v. Snell Constr. Corp., 214 Va. 655, 657-59, 202 S.E.2d 889, $892-93$ (1974). 
whole. Where a zoning scheme is beneficial only to the locality which enacts it but is detrimental to the general welfare of the state and its citizenry, the ordinance will be contrary to its enabling legislation and cannot be upheld. ${ }^{183}$ The importance of scrutinizing zoning ordinances from a statewide perspective was forcefully expressed in the landmark case of Southern Burlington County NAACP v. Township of Mount Laurel, ${ }^{184}$ where the New Jersey Supreme Court held that a developing municipality could not use its zoning systenı to make it physicially or economically inpossible to provide low- and moderate-incoine housing in the municipality for those who need and want it. ${ }^{185}$ According to the

183. See, e.g., Bristow v. City of Woodhaven, 35 Mich. App. 205, 218-19, 192 N.W.2d 322, 328 (1971); Southern Burlington County NAACP v. Township of Mt. Laurel, 67 N.J. 151, 175, 179, 336 A.2d 713, 725, 727-28, cert. denied, 423 U.S. 808 (1975); Berenson v. Town of New Castle, 38 N.Y.2d 102, 110-11, 341 N.E.2d 236, 24243,378 N.Y.S.2d $672,681-82$ (1975). Some of the cases scrutinizing exclusionary zoning have also relied on state law notions of due process and equal protection. See, e.g., Southern Burlington County NAACP v. Township of Mt. Laurel, supra, at 175, 179,336 A.2d at $725,727-28$. However, in this context, the notions of substantive due process, equal protection and the general welfare appear to be inextricably intertwined and little reference is made to the traditional rational basis tests usually employed in due process and equal protection analysis. See Ackerman, The Mount Laurel Decision: Expanding the Boundaries of Zoning Reform, 1976 ILL. L.F. 1, 3-5.

184. 67 N.J. 151,336 A.2d 713, cert. denied, 423 U.S. 808 (1975).

185. 67 N.J. at 174, 179, 336 A.2d at 724, 727. The following extended excerpt from the Mt. Laurel opinion provides valuable insight into the concerns which underlay the court's rejection of the Township's sweeping use of its zoning powers:

There cannot be the slightest doubt that the reason for this course of conduct [exclusionary zoning] has been to keep down local taxes on property . . . .

This policy of land use regulation for a fiscal end derives from New Jersey's tax structure, which has imposed on local real estate inost of the cost of municipal and county government ..... Sizeable industrial and commercial ratables are eagerly sought and lomes and the lots on which they are situated are required to be large enough, through minimum lot sizes and minimum floor areas, to have substantial value in order to produce greater tax revenues to meet school costs. . . .

Almost every [municipality] acts solely in its own selfish and parochial interest and in effect builds a wall around itself to keep out those people or entities not adding favorably to the tax base. ... One incongruous result is the picture of developing municipalities rendering it impossible for lower paid employees of industries they have eagerly sought and welconned with open arms ... to live in the community where they work.

The other end of the spectrun should also be inentioned. ... Core cities were originally the location of most commerce and industry. Many of those facilities furnished employment for the unskilled and seini-skilled. These employees lived relatively near their work, so sections of cities always have housed the majority of people of low and inoderate imcome, generally in old and deteriorating housing. Despite the municipally confined tax structure, commercial and industrial ratables generally used to supply enough revenue to provide and maintain municipal services equal or superior to those furnished in most suburban and rural cases.

The situation has become exactly the opposite since the end of World War II. Much industry and retail busmess, and even the professions, have left the cities. ... The economically better situated city residents helped fill up the iniles of sprawling new housing developments. . . In a society which came to depend inore and more on expensive individual motor vehicle 
court, the general welfare requires each developing municipality to regulate its land use in a manner which permits residential development for a "fair share" of its region's low- and moderate-income housing needs. ${ }^{186}$ Similar decisions have been lianded down in Michigan, New York and Pennsylvania without the explicit restriction to developing municipalities. ${ }^{187}$ At the very least, these decisions require each municipaiity to consider the needs of the larger inetropolitan area of winich it is a part in planning its own development. ${ }^{188}$

Decisions like Mt. Laurel also point out the need for legislative establishment of effective regional planning commissions. The courts appear to recognize that they do not have the expertise to continue to deal with the complexities of regional development and lave only reluctantly taken on this responsibility with respect to zoning to protect what they properly perceive to be the interests of the state. ${ }^{180}$ Such decisions may help to force the legislatures to provide for more effective regional planning. This, in turn, could help to maintain the tax base in the still growing cities of the South and to mitigate the strains on the older cities of the industrial Northeast. ${ }^{190}$

transportation for all purposes, low income employees very frequently could not afford the permissible housing near such locations. These people have great difficulty in obtaining work and have been forced to remain in housing which is overcrowded, and has become more and more substandard and less and less tax productive. There has been a consequent critical erosion of the city tax base and inability to provide the amount and quality of those governmental services-education, health, police, fire, housing and the like-so necessary to the very existence of safe and decent city life. Id. at 170-73, 336 A.2d at 723-24, as excerpted in Peterson 82.

186. 67 N.J. at 174, 188, 336 A.2d 724, 732. An excellent discussion of Mt. Laurel and the concepts of "developing community" and "fair share" can be found in Ackerman, supra note 183.

187. See cases cited in note 181 supra. It seems likely that a balancing test will be employed to apply $M t$. Laurel to developing municipalities in New Jersey as well. See Ackerman, supra note 183, at 15-24.

188. See, e.g., Berenson v. Town of New Castle, 38 N.Y.2d 102, 108-09, 341 N.E.2d 236, 241-42, 378 N.Y.S.2d 672, 679-80 (1975).

189. See, e.g., id. at 109,341 N.E.2d at $241-42,378$ N.Y.S.2d at $679-80$.

190. The practical effects of Mt. Laurel and its progeny may be limited in older established suburban communities whose development is complete, in light of the Supreme Court's recent refusal to impose an obligation on established suburban communities to vary their zoning systems in order to accommodate low- and moderate-income housing. In Metropolitan Housing Dev. Corp. v. Village of Arlington Heights, 517 F.2d 409 (7th Cir. 1975), the Seventh Circuit held that absent a compelling interest, Arlington Heights could not refuse to rezone a piece of property where a variance was the only impediment to the construction of a low- and moderate-income housing development which would help to mitigate a history of racial discrimination in the Chicago metropolitan area. According to the circuit court, to permit the village to refuse the variance would be to allow it to continue to ignore its part in creating a metropolitan housing market which had historically discriminated against blacks and other racial minorities and thus to deprive these minority groups of equal protection of the law. Id. at 414-15. The 


\section{Tax Diversification}

A second alternative available to a city which is unable to expand by physical growth is to expand its tax base through diversification. As different taxes are borne by different segments of an urban economy, diversification may recapture suburban wealth for the central city in varying degrees. ${ }^{101}$ Unlike the property tax which can only be levied on property within the jurisdiction, payroll taxes, sales taxes and user charges can all be used to obtain revenue from individuals and businesses residing outside the city limits. By taxing income or sales at their points of origin, the central cities can recapture part of the wealth which would otherwise be taken to the suburbs.

Over the past twenty years, local governments, particularly the larger cities, have continuously moved toward more diversified revenue systems. ${ }^{102}$ In order to cope with the fiscal problems caused by the decline in their property tax bases, many cities have begun to rely on sources other than the property tax for their local revenues. In 1952, over 60 percent of the municipal taxes collected from local sources were collected through the property tax..$^{193}$ By 1975 , only 42 percent of the cities' local revenues were derived from property taxation. ${ }^{194}$

During the same period, there has been a growth in city dependence on the income tax and the sales tax. Since the authorization of the first local sales tax in New York City in 1934, over 1,245 municipalities in twenty-six states have been permitted to levy a sales tax. ${ }^{195}$ Particularly in the growing cities of the South and Southwest where there has not yet been any rapid movement of retail shops to beyond the city lines, ${ }^{100}$ the local sales tax often plays a highly significant role in city tax structures. ${ }^{197}$ Of the nation's forty-eight largest cities, more than lialf,

Supreme Court, while agreeing that the plaintiffs had standing to sue, held that such official action would constitute an equal protection violation only if intent or purpose to discriminate were shown. The Court found no such intent on the part of Arlington Heights. Village of Arlington Heights v. Metropolitan Housing Dev. Corp., 97 S. Ct. 555 (1977).

191. See generally Local Revenue Diversification; R. Musgrave \& P. Musgrave, supra note 91, chs. 15-20; Stocker, Diversification of the Local Revenue System: Income and Sales Taxes, User Charges, Federal Grants, 29 NAT'L TAX J. 312 (1976).

192. U.S. ADVISGRY COMMISSION ON INTERGOVERNMENTAL RELATIONS, supra note 42 , at 3 ; see id. at 36-38.

193. See id. at 37 (Table XV).

194. See id. (estimate).

195. Id. at 31.

196. See generally Stocker, supra note 191, at 318-19.

197. At least five southern and western cities presently receive over 35 percent of their local revenues from a local sales tax: Denver (41 percent), New Orleans (41.3 percent), Oklahoma City (37.8 percent), Phoenix (39.1 percent) and Tulsa (55 perent). Local REVENUE Diversification 34. 
twenty-six, were collecting a sales tax as of $1972 . .^{198}$ Several states have also authorized local income taxes in recent years. ${ }^{198}$ Of the nation's forty-eight largest cities, at least thirteen presently levy an income tax, ${ }^{290}$ and in nearly half of these the local income tax plays a dominant role in the local tax system. ${ }^{291}$

While data on the commuter contribution to these taxes is not readily available, it does appear that local sales taxes and income taxes (that include non-residents) ${ }^{202}$ can help to recapture substantial amounts of the suburban tax base for the central cities. In a 1971 survey of fourteen local governments, more than one-third indicated that over 25 percent of their income tax collections came from non-residents. ${ }^{203}$ A recent study which estimated the prospective effects of various tax packagcs on the Atlanta metropolitan area concluded that larger portions of the tax burden could be shifted to persons outside of Atlanta through a payroll tax or general sales tax than through a property tax. ${ }^{204}$

Despite the potential advantages of a shift from the property tax, it should be emphasized that city sales and income taxes are still relatively rare. With the exception of a few states where one of these taxes has been given a keystone role in the local tax structure, the dependence on these taxes as a source of local revenues is still quite low. In 1971, income taxes accounted for only 6.8 percent of all local city revenues, and the general sales tax contributed less than 8 percent. ${ }^{205}$

The major reason for the general lack of reliance on local sales and income taxes appears to be fear on the part of states that such measures will disrupt the state economy and cut into state revenues. Local officials also fear that a local sales or income tax will drive consumers and businesses to non-tax or lower-tax commumities, leaving little added

198. Id.

199. Alabama, Delaware, Indiana (counties), Kentucky, Maryland, Michigan, Missouri, New York, Ohio and Pennsylvania. Id. at 52-53.

200. Id. at 53-54.

201. Cincinnati (57.7 percent), Cleveland (47.8 percent), Columbus ( 78.2 percent), Louisville (55.6 percent), Philadelphia (62.6 percent), Toledo ( 74.9 percent). Id. at 54 (Table IV-2).

202. With the exception of Washington, D.C., every major city with a local income tax includes income of non-residents. Id. at 53.

203. Derived from $i d$. (Table IV-3).

204. L. Schroeder \& D. SJoquist, The Property TaX and Alternative Local TAXEs: AN ECONOMIC ANAIYsis ch. 3 (1975). Schroeder and Sjoquist estimated that 47.8 percent of a property tax would be exported outside of Atlanta while 67.6 percent of a payroll tax and 50.3 percent of a general sales tax could be exported. Id. at 94-95.

205. LOCAL REVENUE Diversification 12. 
revenue through the new tax and depressing the tax base at the same time.

With respect to the sales tax, the empirical evidence is somewhat equivocal. ${ }^{200}$ As a general proposition, it seems well established that when imposition of a sales tax results in local tax differentials, a loss of sales revenue will result. ${ }^{207}$ These losses of sales may also be aggravated if they cause businesses to relocate in low tax jurisdictions in order to maximize profits. The extent to which sales revenues will declime, however, depends on a variety of factors. Certain fashion items such as women's clothes or jewelry, for example, may be only minimally affected by a sales tax. ${ }^{208}$ People may feel that such items can only be bought in the fashion center of a central city; there may be no market for the goods outside the high tax jurisdiction; or it may simply be that those who purchase the item are insensitive to the tax differential. A similar indifference is often noted with respect to low-price items or necessities such as groceries, for which consumers are reluctant to leave their neighborhoods. ${ }^{209}$ One study in Colorado actually concluded that, although a temporary loss in sales occurred just after a new sales tax was imposed in Denver, the market eventually returned to its pre-tax sales level. ${ }^{210}$

From a local point of view, much of the "border problem" can be alleviated if all jurisdictions in a particular state can and do impose a particular tax. In a state like Illinois, for example, local sales taxes have only a minimal effect on intrastate location and purchasing decisions since all of the state's 100 counties and 1,245 municipalities impose the tax. $^{211}$ Interstate effects are also negligible since in many cases consumers are too far from state borders to bother to make the journey.

The absence of major interjurisdictional tax differences also reduces adverse effects from local income taxes. ${ }^{212}$ In general, local

206. See id. at 39-40.

207. The leading study in the area is Mikesell, Central Cities and Sales Tax Rate Differentials: The Border City Problem, 23 NAT'L TAx J. 206 (1970). See also LocaL Revenue Diversification 39-40; Hamovitch, Sales Taxation: An Analysis of the Effects of Rate Increases in Two Contrasting Cases, 19 NAT'L TAX J. 411 (1966); McAllister, The Border Tax Problem in Washington, 14 NAT'L TAX J. 362 (1961).

208. Cf. McAllister, supra note 207, at 368.

209. See id.

210. See Local Revenue Diversification 39.

211. See id. at 32, 38. California and Washington also appear to have near-universal sales tax coverage. Id. at 38 . The absence of any major sales tax differential was the most frequent reason advanced for the lack of location effects in a recent study in which 173 out of 178 municipal finance officers opined that their local general sales tax had not resulted in a loss of business for their communities. Id. at 38-39.

212. See id. at 58.59 (reporting results of a Municipal Finance Officers Association/ 
income tax rates are relatively low, and this has minimized incentives to relocate. $^{213}$ More importantly, since the burden of income taxes is almost completely on the taxpayer, ${ }^{214}$ the tax will rarely affect location decisions when it is imposed at the place of work rather than at the place of residence. Unless corporate tax or personal tax considerations in a close corporation or small partnership cause his employer to move, an individual may be unable to avoid the tax without finding a new job. Businesses themselves will be unlikely to undertake a costly move in order to secure a small tax advantage for their employees. If, on the other hand, the tax was imposed at the place of residence, individuals might avoid it by changing residences without forsaking their jobs.

The one criticism to which local sales and income taxes are clearly vulnerable is that they often make rich jurisdictions richer with much less substantial returns for poorer communities. ${ }^{215}$ This difficulty can only be overcoine by state-imposed equalization or revenue-sharing programs.

\section{Federal Aid}

Federal aid is an increasingly significant factor in local government finance. During the last decade, such aid increased at an average yearly rate of 15 percent, whereas the rate had been less than 10 percent in the previous ten years. ${ }^{216}$ By 1975, state and local governments obtained 30 percent of their revenue from federal aid, more than double the percentage contribution of federal funds in the $1950 \mathrm{~s}^{217}$ For declining major cities external aid has been particularly important, with combined state and federal aid making up froin about one-half to two-thirds of the growth in revenues over this period. ${ }^{218}$ As a result, aid to state and local government has gone from 10 percent of federal outlays in 1966 to 17 percent in 1976. Given the continuation of the policies contained in current law alone, federal aid is expected to increase another 30 percent by $1981 .{ }^{219}$ This rapid increase in federal aid during the last decade has

U.S. Advisory Commission on Intergovernmental Relations survey in which forty-eight out of fifty-four city managers indicated that the imposition of an income tax by their jurisdiction had not resulted in losses of population or business firms). See generally R. SMITH, LOCAL INCOME TAXES: ECONOMIC EFFECTS AND EQUITY (1972),

213. R. SMith, supra note 212, at 9, quoted in Local Revenue Diversification 58. 214. See J. Brittain, The Payroll Tax for Social Security (1972); R. MusGrave \& P. Musgrave, supra note 91 , at 403-14.

215. See Local Revenue Diversification 40-44, 59.

216. See Peterson 59 (Table 9).

217. Sunley, supra note 9 , at 382 .

218. Peterson 59-60 (Table 10).

219. See Congressional Budget Office, Budget Options for FY 1977, at 246 
been accompanied by a shift from narrowly restricted special purpose categorical grants to more general purpose block grants whose funds are distributed according to formulas based on local community characteristics. Whereas block grants did not even exist a decade ago, by 1975 they made up almost 25 percent of the federal aid package with more than half of this being in the form of general revenue sharing. ${ }^{220}$ This percentage is currently being further increased, at least temporarily, by emergency anti-recession aid in the form of funds for public employment and temporary fiscal aid for state and local governments. ${ }^{221}$

While there is general approval of this trend toward greater reliance on general purpose block grants and broad agreement on the need for emergency anti-recessionary aid, some fundamental disagreements have arisen over the way these funds are allocated. Since major portions of the basic authorizing legislation for these programs will expire in fiscal year 1977, this issue will have to be addressed in the first session of the 95th Congress. ${ }^{222}$

Much of the dissatisfaction with the current pattern of federal expenditures is concentrated in the northern industrial states and their major metropolitan areas. ${ }^{223}$ The factors which are most often cited are the higher unemployment rates in the North during the recession, ${ }^{224}$ the imbalance between the federal taxes which the northern states pay and the federal expenditures that are returned to the region, ${ }^{225}$ and the rapid

(1976). However, projections also suggest that such aid will fall to only 14 percent of federal outlays in 1981. Id. at 248. If state and local aid is to retain its current share of outlays, it will therefore have to grow at an even faster rate.

220. Id. at 248, 253-54.

221. The public employment funds are authorized under the recently modified Title VI of the Comprehensive Employment and Training Act of 1973, 29 U.S.C.A. \$\$ 961 et seq. (Supp. 1976), and the countercyclical revenue sharing funds are authorized under Title II of the new Public Works Employment Act of 1976, Pub. L. No. 94-369, 42 U.S.C.A. $\$ \$ 6721$ et seq. (Supp. 1977).

222. The Comprehensive Employment and Training Act of 1973, the Housing and Community Development Act of 1974, and Title II (Antirecession Provisions) of the Public Works Employment Act of 1976 all expire in FY 1977. See 29 U.S.C.A. \$ 802(a) (Supp. 1976), 42 U.S.C.A. \$ 5303 (a) (Supp. 1976), and 42 U.S.C.A. \& 6722(b) (Supp. 1977) respectively.

223. See, e.g., The Future of the Northeast, 2 EmpIRE STATE Report 332-33, 343-45 (1976); Havemann, Stanfield \& Peirce, supra note 11; Jusenius \& Ledebur, supra note 159, at 1; Leone, The Fiscal Decline of Older Cities: Causes and Cures, 29 NAT' TAX J. 257 (1976) (Mr. Leone is the New Jersey State Treasurer); Special Report: The Second War Between the States, Business WeEK, May 17, 1976, at 92.

224. In 1975, the North had an unemployment rate of 9.9 percent, compared to 8.3 percent in the South. However, this difference almost disappears if one does not count the northern Virginia suburbs near Washington and the energy-rich states of Texas and Oklahoma. Jusenius \& Ledebur, supra note 159, at 29.

225. In the North, the average federal tax collection was $\$ 1,561$ per person in 1975 
increase in personal income $e^{226}$ and manufacturing employment ${ }^{227}$ in the South relative to the North.

Since the programs through which changes in the pattern of federal expenditures could most easily be made are those involving grants to state and local governments, ${ }^{228}$ a great deal of attention has been focused on allocation formulas. However, it is in the grant area that the northern states enjoy their only advantage in federal expenditure patterns, ${ }^{229}$ presumably due to their success in applying for the early categorical programs. This advantage has been at least partly perpetuated in the block grant programs by various "hold harmless" provisions designed to prevent any precipitous declime in aid when old categorical programs are combined in a new block grant. This is an issue of particular concern to the northern states im the reauthorization of the Community Development Block Grant Program. According to the original legislation, the Program's "hold harmless" provisions are scheduled to be phased out by $1981 .^{230}$ The northern metropolitan areas, which are generally the ones with the most to lose, wish to retain the "hold harmless" feature or to introduce another factor into the formula, such as the age of the local housing stock, which would have roughly the same effect. ${ }^{231}$

whereas federal expenditures averaged only $\$ 1,260$ per person. In the South, on the other hand, taxes were $\$ 1,188$ while expenditures were $\$ 1,356$. While the South did receive more than the North in federal expenditures per capita in 1975 , both regions received less than the national average federal expenditure of $\$ 1,412$ per person. Id. at 44.

226. From 1960 to 1975 , real personal income in the Southeast grew 114.3 percent compared to only 65.5 percent in New England, 57.8 percent in the Mid-Atlantic states and 65.1 percent in the Great Lakes region. However, per capita income in these Northern states has remained fairly constant at between 105 percent and 120 percent of the national average since World War II. While per capita income in the South has steadily closed the gap, it is still only 80 percent of the national average. The Future of the Northeast, supra note 223 , at 342-43.

227. Manufacturing employment in the Northern states declined by 12.7 percent from 1970 to 1975 , reflecting the nationwide decline in this type of industry and the heavy reliance of the Northeast on it. Largely because of this decline, overall employment in the North grew by only 1.3 percent over the same period; employment in the South grew by 16.7 percent, mainly because of the substantial growth of jobs in state and local government (up 23.5 percent) and the service industries (up to 30.8 percent). However, few of the Northern job losses were due to firms migrating to the South. Between 1969 and 1973, the percentage of employment losses due to migration of firms from the North was only 1.5 percent. Jusenius \& Ledebur, supra note 159 , at $34,40$.

228. It is much more difficult to change the flow of funds in defense spending and Social Security, for example.

229. Haveman et. al found that the Northeast received $\$ 260$ per capita in federal grants to state and local governments in 1975 while the South received only $\$ 220$ per capita. Haveman, Stanfield \& Peirce, supra note 11, at 880.

230. 42 U.S.C.A. $\$ 5306$ (g) (Supp. 1976).

231. BNA Housing AND DEv. REP. 283 (1976). 
Action on this proposal or on a number of others currently being advanced $^{232}$ would continue or expand the dominance of the northern states in obtaining grants to state and local governments. The impact of such changes would largely be felt in the areas of government services and assistance to low-income individuals. It would appear to be inappropriate to divert such federal funds from other regions that still have the greatest poverty and the lowest income in our nation in order to redress a regional imbalance in other federal expenditures.

Proposals to modify the distribution of emergency anti-recession funds are another matter. The two anti-recession programs, public service jobs and countercyclical state and local fiscal aid, are aimed at getting money into consumers' hands quickly and at helping local governments avoid the cut-backs that would tend to make the recession worse. Proposals to direct these temporary funds to the areas where the recession has hit the hardest, particularly in the industrial Northeast, are therefore more appropriate. ${ }^{233}$

\section{FINANCING}

As cities have sought to remedy their increasing imbalance of revenues and expenditures, the role of debt financing in their financial structures has also changed. In recent years, an increased need for capital from tight money markets has resulted im important changes in the cities' use of both long- and short-term debt financing and in the structure of the capital markets in which this debt is obtained.

\section{A. Long-Term Debt}

The use of long-term debt (i.e., debt with a maturity longer than one year) has a relatively stable history. In the late 1950 s and through the 1960s, proceeds from the sale of bonds and other long-term debt instruments consistently contributed roughly 50 percent of the funds needed for state and local capital expenditures. ${ }^{234}$ In the 1970s, this

232. See, e.g., Recommendations of Federal Grants Formulas Panel to CoalitION OF NORTHEASTERN GOVERNORS (1976).

233. The Coalition of Northeast Governors has recommended a two-tier unemployment trigger ( $4 \frac{1}{2}$ percent and $61 / 2$ percent) for the distribution of countercyclical revenue sharing funds in order to target more of the funds to high unemployment localities. RECOMMENDATIONS, supra note 232, at 4.

234. Fortune, Financing PL 92-500: The Impact of the Federal Water Pollution Control Act of 1972 on the Municipal Bond Market, in Data Resources, INC., WATER Pollution Control Act of 1972: Economic Impacts, State and Local Revenues EXPENDITURES 18 (Appendix B) (National Technical Information Service, No. PB 250018 1975). 
proportion has been somewhat higher, averaging around 60 percent. However, while the use of long-term debt in capital financing has been fairly steady over long periods, it has also been highly volatile in the short run due to fluctuations in interest rates and in the availability of capital. For all United States mumicipalities, for example, the ratio of debt financing to capital expenditures varied from 66 percent to 54 percent and back to 68 percent over the three fiscal years 1969,1970 and $1971 .{ }^{235}$ In fiscal 1975, the proportion of capital expenditures financed through indebtedness again dropped precipitously to only 47 percent, a decrease of 33 percent from the previous fiscal year. ${ }^{236}$

Among local governments, the heaviest reliance on debt financing has been in the cities, and the larger the city the greater the reliance has been. In fiscal 1974, the twenty-nine cities with populations above 500,000 had a ratio of debt to capital expenditures of 82 percent compared to only 61 percent for all other cities. While the higher dependence on debt in larger cities appears to persist over time, cities of all sizes have experienced great volatility in their dependence on longterm debt. In fiscal 1975, large cities depended on indebtedness for only 52 percent of their capital expenditures while smaller cities had reduced their ratio of debt to capital expenditures to 45 percent. $^{237}$

This volatility in debt fimancing has its origins in the basic structure of the market for municipal debt. Because the interest on most municipal bonds is tax-exempt, ${ }^{238}$ these bonds are most attractive to those individuals and institutions who are subject to high tax rates. In the past, this has meant that the market relied primarily on wealthy individuals and commercial banks for its capital supply. More recently, the market has expanded slightly to imclude increasing numbers of fire and casualty insurance companies. ${ }^{239}$ However, the number of investors who find tax-exempt inunicipal bonds attractive is clearly limited. Most individuals cannot afford to exchange the higher interest rates of the private sector for the tax exemption on municipal bonds, and many of the large institutional investors such as pension plans and charitable organizations are currently exempted from federal income taxes and therefore

235. See U.S. Bureau of the Census, City Government Finances in 1969-70, at 5-6 (Table 1) (1971); U.S. Bureau of The Census, City Government Finances IN 1973-74, at 7-8 (Table 1) (1975).

236. U.S. Bureau of THE Census, City Government Finances IN 1974-75, at 5-6 (Table 1) (1976).

237. Id. at 7 (Table 3 ).

238. See InT. Rev. CoDe of $1954, \S 103$ (a).

239. See U.S. ADVISORY COMMISSION ON INTERGOVERNMENTAL RELATIONS, Understanding the Market for State and Local Debt 17-18 (1976). 
have no incentive at all to purchase municipals. As a result of this tight capital supply, municipal bond markets are extremely sensitive to any changes in either the supply or demand for capital. On the one hand, in periods where state and local governmental demand for capital is up, the limited supply of capital may cause interest rates to rise precipitously. ${ }^{240}$ On the other hand, any constriction of the money supply in the overall capital market would directly affect the participation of commercial banks in the market for long-term municipal debt. As they are the largest source of funds for municipal debt fimancing, any departure of the commercial banks would make municipal indebtedness hard to sell and would drive up interest rates. Both of these factors have contributed to recent increases in interest rates on municipal bonds. ${ }^{241}$

TABLE 4 City Debt Financing FY-1969 to FY-1975

Long-Term Debt

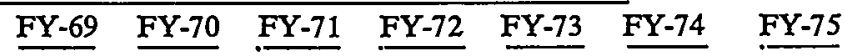
Issued as a Percentage of Capital Expenditures 66 $54 \quad 68 \quad 76$ $67 \quad 69$ 47

Short-Term Debt Outstanding as a Percentage of Total Debt Outstanding Short-Term Debt as a Percentage of Total Debt Issues

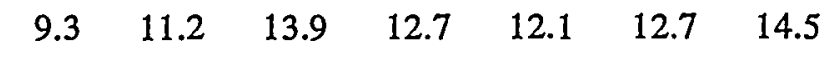

Percentage Increase in Capital

Expenditure

$\begin{array}{llll}47 & 56 & 56 & 5\end{array}$

52

53

62

Yields of Twenty-Year

Medium Grade

Municipal Bonds

$\begin{array}{lll}14 & 10.1 & 10.4\end{array}$

$5.0 \quad 11.5$

7.9

21.8

SOURCES: Derived from U.S. BuREaU OF THE CENSUS, CITY GovernMent FinanCes for selected years, 1968-69 through 1974-75, Table 1 (the items used are Capital Outlay, Gross Debt Outstanding, Short-Term, Long-Term Debt Issued); U.S. ADVISORY COMMISSION ON INTERGOVERNMENTAL RELATIONS, UNDERSTANDING THE MARKET FOR STATE AND LOCAL DEBT, Exhibit A-4, at 36-38 (1976).

240. Some of the recent increases in municipal interest rates may be due to increases in the amount of debt financing undertaken by the states. Prior to 1965 , debt financing supplied funds for only 36 percent of state capital expenditures while local governments drew closer to 70 percent from debt financing. See Fortune, supra note 234, at 182 (Table I.6). In fiscal 1975, both state and local governments relied on long-term debt for almost 50 percent of their capital expenditures. See U.S. BUREAU OF THE Census, Governmental Finances iN 1974-75, Tables 9 (capital expenditures) and 14 (longterm debt issue) (1976).

241. See U.S. ADvisory Commission, supra note 239, at 36-38 (Exhibit A-4). See Table 4 supra. 
The reaction of the cities to these periods of limited funds and high interest rates has been to finance larger portions of capital expenditures from short-term debt. This trend is illustrated by the data presented in Table 4. The taxable bond option has often been proposed as the solution to this problem. ${ }^{242}$ Under this proposal, state and local governments would be free to offer taxable bonds. In order to compete with the corporate bond market, those bonds would have to be sold at higher interest rates, which would appeal to investors who cannot currently take advantage of a tax exemption and which would thus broaden the supply of debt funds. In order to mitigate the costs of those higher interest rates, the federal government would provide a subsidy to the local government approximately equal to the difference between the interest rates on taxable and tax-exempt bonds so that the local governments would have the same interest cost regardless of whether they chose to market taxable or tax-free debt.

This approach to broadening the market for municipal debt has two particularly appealing features: it would save money for the public sector and reduce tax exemption benefits to the wealthiest municipal bondholders. Under the exemption, much of the federal subsidy goes to the wealthiest purchasers of tax-exempt bonds ${ }^{243}$ and the city receives interest cost savings in the municipal bond markets that are only a fraction of lost federal meome tax revenues. A taxable bond with a direct federal subsidy would insure that the municipalities actually receive all of the benefit while elimimating special tax benefits to the wealthy. Perhaps more importantly, the taxable bond would also result in an overall savings to the public sector, since the increased federal revenues from taxation of bond interest are expected to exceed the direct federal subsidy necessary to offset the increased interest costs to state and local governments. It has been estimated that the tax exemption on municipal bond interest costs the federal governnient about $\$ 1.50$ in foregone

242. E.g., American Enterprise Institute, Proposed Alternatives to Tax Exempt State and Local Bonds (1973); J. Petersen, Changing Conditions in the Market for State and Local Government Debt, 52-64 (Comm. Print 1976) (prepared for Joint Economic Comm. of Congress, 94th Cong., 2d Sess.); Sunley, supra note 9, at 395-400. For a useful analysis of the economics of the taxable bond alternative, see Fortune, supra note 234, at 122-24, 139-48.

Several proposals to adopt the taxable bond option have been introduced in Congress, see AMERICAN ENTERPRISE INSTITUTE, supra; versions of the Tax Reform Acts of 1969, 1973, and 1976 each included proposals for taxable municipal bonds. See, e.g., H. 1039, 91st Cong., 1st Sess. (1969); H. 2142, 91st Cong., 1st Sess. (1969); S. 1439, 93d Cong., 1st Sess. (1973); H. 967, 93d Cong., 1st Sess. (1973); S. 512, 94th Cong., 1st Sess. (1975); H. 2702, 94th Cong., 1st Sess. (1975).

243. See, e.g., J. PETERSEN, supra note 242, at 58-60. 
income tax revenues in order to reduce state and local interest costs by $\$ 1.00 .^{244}$ With a direct subsidy, this inefficiency would be elininated. In 1975, this device could have saved the federal government $\$ 1.4$ billion. ${ }^{245}$ Finally, in addition to lower costs, the taxable bond should help to stabilize the municipal bond market by expanding the supply of available capital.

Use of a taxable bond option should not be impeded by constitutional considerations. While there was some concern in the early tax cases over whether or not the Constitution would allow taxation of interest on municipal bonds, ${ }^{240}$ 1nost commentators would now agree that this is not a problem. ${ }^{247}$ Such a tax would not be imposed on governments, but on citizens, and its impact would be no different from that of taxing any other revenue which a private individual derives from a governmental employer or contract. ${ }^{248}$ Since there is no direct interference with state or local governments' freedom to conduct their own affairs, but rather an addition to the list of available options, National League of Cities v. Usery would not dictate a different result. ${ }^{249}$

\section{B. Short-Term Debt}

Short-tern debt (i.e., debt which matures in one year or less) currently serves two major functions in municipal fimance: shortterm loans inay be used to smooth out revenue flows in anticipation of tax payments or intergovernmental grants that are due but have not yet been received, and they nay be used to provide flexibility so that cities can take advantage of fluctuating market conditions in the timmg of their long-term debt offerings. The principal instrument used to smooth out seasonal variations in the inflow of revenues is the revenue anticipation note, which is issued to raise funds in advance of actual collcction of taxes. The principal instrument used to create flexibility

244. Sunley, supra note 9, at 396; see R. Goode, Individual Income TAX 136 (rev. ed. 1976). See also J. Petersen, supra note 242, at 55-58; Comparison of the Interest Cost Saving and Revenue Loss on Tax-Exempt Securities, ch. 20 in Staff of Subcomm. on Economic Progress of the Joint Economic CoMm. of Congress, 89th Cong., 2D Sess., State and local Public Facility Needs and Financing: Public Facilmy Financing 327-33 (Comm. Print 1966); Fortune, supra note 234, at 129-31; 138-47.

245. Sunley, supra note 9, at 396; see J. PETERSEN, supra note 242, at 55-58.

246. E.g., Pollack v. Farmers' Loan \& Trust Co., 157 U.S. 429, 585-86 (1895).

247. See, e.g., Kirby, State and Local Bond Interest, in HouSE COMM. ON WAYS AND Means, 86th Cong., 1st Sess., Tax Revision Compendrum pt. 1, at 679, 682 (1959).

248. It is well established, for example, that salaries of state and local government employees may be taxed by the federal government. See note 88 supra and accompanying text.

249. See notes 81-89 supra and accompanying text. 
in the timing of long-term bond offerings is the bond anticipation note. This device enables funds to be raised to meet capital expenditure requirements in a timely manner while allowing the long-term debt offering to be temporarily delayed until interest rates fall.

Beginning with the late $1960 \mathrm{~s}$, the volume of short-term debt incurred by state and local governments has increased markedly. Between 1968 and 1970 short-term debt doubled; by 1971, it had tripled. ${ }^{250}$ In 1970, the volume of short-term borrowing by state and local governments actually exceeded long-terin borrowing for the first time. $^{251}$ Even so, the reliance on short-term debt by these governments was still relatively modest in comparison to the total amount of debt outstanding. Short-term debt still constituted only 8.9 percent of outstanding state and local indebtedness in fiscal 1975. ${ }^{252}$

Withm the state and local sector, the cities, particularly the large cities, have always relied more heavily on short-ternn debt, and the municipalities were vigorous participants in the rapid expansion of short-term debt use between 1969 and 1974. ${ }^{253}$ In fiscal 1969, shortterin debt accounted for slightly less than half of the total indebtedness incurred by the cities. During the early 1970s, this proportion increased slightly and remained fairly steady at about 54 percent of debt issued. In fiscal 1975, fully 62 percent of all debt issued by the cities was short-terin as the cities sought to fund a big surge in capital expenditures which occurred in that year. ${ }^{254}$

The pattern which emerges from the data in Table 4 is indicative of some of the basic forces at work in the narket for municipal debt. In periods during which capital expenditures increase substantially (fiscal 1970 and 1975), demand for long-terın debt will also increase. This increase in demand will lead to higher interest rates. In order to minimize their interest costs, the cities will then turn to short-term financing in the hope that interest rates will decline. This shift in financing emphasis will yield lower proportions of long-term debt relative to capital expenditures and heavier use of short-term debt as a proportion of debt issued.

The pressure for cities to shift to short-term debt appears to have been particularly intense in the larger cities. Even as early as fiscal

250. See U.S. AdVISORY COMmission ON INTERgovernmental RElations, supra note 239, at 35 (Exhibit A-3). See also J. PETERSEN, supra note 242, at 2, 4-10.

251. See U.S. Advisory Commission, supra note 239, at 35 (Exhibit A-3).

252. Derived from U.S. Bureau of the Census, Governmental Finances in 197475 , at 26 (Table 14) (1976).

253. See Table 4 supra.

254. Id. 
1969, the twenty-nine largest U.S. cities used short-term financing for more than half of the total debt which they issued. By fiscal 1975, a year of heavy short-term debt use by all governments, short-term debt constituted almost three-quarters of the debt issued by these large cities. $^{25 s}$

This new heavy reliance on short-term debt by large cities was brought into dramatic focus by the recent financial crisis in New York City. ${ }^{250}$ In 1975, New York City faced debt service obligations ${ }^{257}$ which amounted to approximately 40 percent of total outlays of funds. This amount of debt service was exceptionally high relative to other cities and even relative to previous years in New York itself. ${ }^{258}$ The reason this tremendous level of debt payments was generally thought to be manageable was because so much of it ( 80 percent) was short-term debt that could be "rolled over," i.e., covered by new short-term borrowing. The crisis was precipitated by the unexpected inability of New York to "roll over" its short-term debt.

The default of the Urban Development Corporation (a quasi-state agency) on $\$ 104.5$ million in short-term notes made underwriters nervous and prompted them to withdraw from an issue of New York City tax anticipation notes. When the City later attempted another issue of short-term notes, it was able to sell only about 40 percent of the issue. Finally, when $\$ 792$ million in short-term obligations came due in June 1975, New York found that it could not borrow the funds to cover the payments. At that point the Municipal Assistance Corporation was established; this action was followed in short order by creation of the Emergency Financial Control Board and by federal financial assistance.

The New York crisis has its parallel in corporate finance. In 1970, the failure of the Pcnn Central and its default on large amounts of commercial paper shook investor confidence and made it virtually impossible for some other corporations to roll over their own commercial paper as it matured. During the summer of 1970 , several major corporations watched their cash drain away as they paid off mature obligations and were unable to find new lenders in sufficient numbers. In

255. In fiscal 1968 , for cities with more than 500,000 population, 54.6 percent of all debt issued was short-term. By fiscal 1975, this percentage was up to 73.8 percent. Derived from U.S. Bureau oF the Census, City Government Finances in 1968-69 (1970) and U.S. Bureau of the Census, City Government Finances in 1974-75 (1976).

256. For a description of the New York City crisis, see Shalala \& Bellamy, A State Saves a City: The New York Case, 1976 Duke L.J. 1119.

257. "Debt service" includes both interest payments and repayment of debt principal.

258. In 1965, for example, these obligations had amounted to only about 25 percent of total obligations in New York. 
order to make short-term bank credit available to these businesses, the Federal Reserve took steps to increase the liquidity of commercial banks. ${ }^{250}$ Since that experience, investors in commercial paper have looked much more closely at the financial condition of borrowing corporations.

Both the New York situation and its counterparts in corporate finance involved a heavy reliance on particular forms of short-term debt, a liquidity crunch caused by a sudden loss of investor confidence, closer investor scrutiny of the financial data supplied by the borrowing community, assistance from the federal government, and a move to more cautious lending policies and fuller disclosure by borrowers. More careful examination of municipal issues by investors and underwriters should help to prevent the recurrence of these circumstances in the mumicipal bond market in the future.

\section{CONCLUSION}

This review of the financial problems facing our largest cities makes it clear that the central responsibility for maintaining the fiscal integrity of America's major urban centers cannot be left solely with the cities themselves. While careful management and urban planning can help some of the younger cities to maintain their current positions of financial strength, many of the older urban centers are already experiencing serious financial difficulties and have only a limited capacity to control expenditures or to expand their revenue resources. Although expenditure growth can be controlled in certam areas (for example, by restructuring municipal employee pension plans), there is little that the cities can do to offset the costs of inflation or of the additional services required by their citizens. Even the younger cities which are still growing have only limited powers to expand their boundaries or to diversify their revenue systems in an effort to recapture their revenue bases as central city residents and busimesses relocate in the suburbs or in other regions.

The federal government is also unlikely to make any major contribution to the solution of the large cities' financial problems. After a decade of expansion, the growth of federal aid as a proportion of city revenues now appears to be reaching its natural limits, at least for many of the more hard-pressed big cities which have been among the most aggressive seekers of federal funds. Even with continued expansion of

259. See 1970 FED. Reserve Bull. 605; Business WeEX, June 27, 1970, at 40. 
federal grant programs, the increasing emphasis on formula-based aid programs will tend to spread the funds broadly across many communities so that program increases are unlikely to be a major source of funds for the older cities. Temporary countercyclical aid should help to ameliorate the financial strain on cities during periods of greatest stress, and implementation of such proposals as the taxable bond option can do much to broaden and stabilize the market for mumicipal debt and to improve the efficiency of the subsidy already inherent in the tax exemption. However, neither of these programs, nor the many other federal actions that have been proposed, has the capacity to shift the cities from positions of fiscal strain to positions of fiscal strength. The cities simply cannot rely on the federal government to continue to provide funds to support the higher and higher levels of municipal expenditures which they are increasingly unable to fund from their own revenue sources.

Primary responsibility for reducing the strain on city finances must be borne by the states. The capacity of the central cities to extend their boundaries through annexation or to extend their revenue bases through sales or income taxation is almost totally dependent on state authorization. Only the states can provide the growing cities with the flexibility they need to continue to expand with their market areas, and thereby avoid those obstacles to the growth of their taxing jurisdictions that have contributed to the fiscal difficulties currently faced by the older central cities.

Several options are also available at the state level for mitigating the strain on older cities which are no longer growing. Regional forms of government or regional or state assumption of particular services may be used to reunite the cities with their natural market areas. To the extent that proposals for regionalization or state assumption of services can be implemented with a minimum of new administrative costs, and in such a way that the central cities already in financial difficulty are not forced to assume the additional expense of revenue contributions for use in other hard-pressed communities, such alternatives should be carefully considered..$^{200}$

Where political or economic considerations make regional or state assumption of services or the costs of those services infeasible, the states

260. See generally R. BaHL \& W. Vogt, Fiscal Centralization and Tax BuRdens: State and Regional Financing of City Services (1975); Bahl \& Puryear, Regional Tax Base Sharing: Possibilities and Implications, 29 NAT'L TAX J. 328 (1976); Special Symposium, State and Regional Government Financing of City Government Services: Tax Burdens and Budgetary Implications, 29 NAT'L TAX J. 53 (1976); Stephens, The Metropolitan Impact of Fiscal and Governmental Reforms: A Simple Model of the Metropolis, 7 URBAN LAW 495 (1975). 
should consider regional or statewide revenue sharing as a vehicle for relieving fiscal strain in the central cities. Particularly in growing metropolitan areas where migration is from the cities to the suburbs rather than out of the metropolitan area as a whole, regional sharing of any continued growth in the metropolitan tax base may help to mitigate revenue losses by the central city. Under Minnesota's Metropolitan Revenue Distribution Act, for example, each of the seven counties in the Twin Cities Area is required to contribute 40 percent of any increase in revenues from taxes on commercial and industrial property to an areawide pool from which tax receipts will then be redistributed among municipalities in the area according to their populations and per capita valuations of taxable property. ${ }^{201}$ While there has been some criticism of this program because of its focus on changes in the commercial/industrial, rather than the more substantial residential tax base, ${ }^{262}$ the thrust of the plan is both innovative and properly focused. Through the redirection of new metropolitan area revenue resources back toward the central cities, the cities may be enabled to continue to provide services that are used by the entire metropolitan area. Where the entire metropolitan area is declining, statewide revenue sharing, power equalization programs or assumption of services at the state level may be the only alternatives available to bolster the financial picture of the declining region.

Whatever course of action is ultimately selected, it seems clear that the states must assume a more active role in maintaining the financial strength of America's cities. The recent period of increasing federal responsibility for financing the cities has come to a close, and the problems of financing municipal services can no longer be left to local officials. A new era of vigorous state action is now required.

261. Minn. Stat. AnN., \$\$ 473.01-.13 (Supp. 1977); see Village of Burnsville v. Onischuk, 301 Minn. 137, 222 N.W.2d 523, appeal dismissed, 420 U.S. 916 (1974) (rejecting challenge to the act based on state constitutional provision requiring that taxes be uniform upon the same class of subjects).

262. See Peterson 81. 
